\title{
43. SEDIMENTOLOGY OF THE WESTERN CONTINENTAL SLOPE OF CENTRAL AMERICA ${ }^{1}$
}

\author{
Miriam Baltuck, Department of Geology, Tulane University \\ Roland von Huene, U.S. Geological Survey, Menlo Park, California \\ and \\ Robert J. Arnott, Shell International, The Haag²
}

\begin{abstract}
The Middle America active continental margin is the best-sampled active plate margin to date, having been drilled during Legs 84,67 , and 66 . With nine sites drilled on the continental slope of Guatemala and an additional site drilled on the Costa Rican slope, a summary of slope sediments and sedimentary processes can be made.

Sediments are easily subdivided into a thick apron of Neogene and Quaternary volcanically derived hemipelagic and turbidite mud and mudstone and a thinner, more varied assemblage of mostly Paleogene mudstone, radiolarian mudstone, and limestone. This latter assemblage may contain hiatuses or be completely lacking between slope deposits and basement. Cores from the foot of the continental slope (Core 567A-19) consist of Campanian micrite. The pre-Neogene section is much thicker and of more terrigenous provenance beneath the forearc basin landward of the forearc structural high than on the continental slope.

Sedimentary processes of the Neogene and Quaternary slope sediments include reworking of hemipelagic and turbidite deposits. Redeposition by slumping, plastic flow, and turbidity current-documentable through benthic foraminiferal analysis-occurs in intracanyon and canyon settings. Erosion by slumping and by turbidity current and deposition of mud or sand in canyons and in local depressions on the continental slope and different rates of sediment accumulation result in dramatic thickness variations of lithologic units over small distances in localized pockets of sand in small filled canyons on the slope or in sediment ponds, and in high-relief basement topography. The age of sediment overlying igneous basement ranges from Cretaceous to Quaternary.

Gas hydrate was visible or inferred present at every site drilled during Leg 84 . Nevertheless, except for a small amount in the last core, it was not recovered in sufficient quantities to be visible at Site 568, a site specifically chosen for the study of hydrate and located near Site 496, which was abandoned during Leg 67 because of the dangerous abundance of hydrates. The association of hydrate with porous, coarser sediment results in a distribution as localized and unpredictable as the slope sands off Guatemala, which do not occur in beds coherent enough to produce acoustic reflection.

Although the normal lithologic section at Sites 567 and 496 limits the volume of sediment that could be part of an accretionary prism offshore Guatemala and the volume of sediment in the Trench axis is not sufficient to argue for significant accumulation of Cocos Plate sediments, the varied lithology and attenuated thickness of pre-Neogene sediment seaward of the forearc structural high do not exclude earlier accretion from the history of the Guatemalan continental margin.
\end{abstract}

\section{SEDIMENTOLOGY OF THE WESTERN CONTINENTAL SLOPE OF CENTRAL AMERICA}

\section{Introduction}

Despite their prominence in plate tectonic theory, active continental margins are poorly known. Because they are structurally and bathymetrically complex, involve settings of great water depths, are commonly blanketed by a thick pile of slope sediments, and are of little importance as hydrocarbon sources, they have not been sampled or surveyed as thoroughly as passive margins.

The active margin off Guatemala (Fig. 1) was a focal area in a series of papers (Seely et al., 1974; Seely, 1979) modelling trench and slope features of subduction complexes. The model depicts offscraping of rocks and sediments from the downgoing plate onto the front of the continental margin to form a growing "accretionary

\footnotetext{
${ }^{1}$ von Huene, R., Aubouin, J., et al., Init. Repts. DSDP, 84: Washington (U.S. Govt. Printing Office).

2 Addresses: (Baltuck) Department of Geology, Tulane University, New Orleans, LA 70118; (von Huene) U.S. Geological Survey, Menlo Park, CA 94025; (Arnott) Shell International, The Haag, The Netherlands.
}

prism" (Karig and Sharman, 1975) and could be applied to explain large landward-dipping acoustic reflectors in the Guatemalan margin as imbricated sheets of accretionary rocks and sediments (Ladd et al., 1982).

Deep-sea drilling off Japan and the Marianas during Legs 56 and 60 showed alternatives to the accretionary prism model: forearc sediments did not consist of materials offscraped from the surface of the downgoing plate. Furthermore, sediment budget calculations for these and also for the Peru-Chile Trench indicate that the volume of forearc sediments is drastically less than would be expected in an accretionary setting (Scholl et al., 1977).

Leg 67 was designed to test the accretionary trenchslope model in its type area, where rapid plate convergence rates (Minster and Jordan, 1978), distinctly different sediments on the slope (diatomaceous muds) and on the downgoing Cocos Plate (foraminiferal-nannofossil chalk), and diverse tropical microfossil assemblages would provide the stratigraphic and lithologic resolution necessary to distinguish between accretion and subduction of sediments, as well as imbricate thrusts, sediment slumping, or continental marginal failure. The mission was 


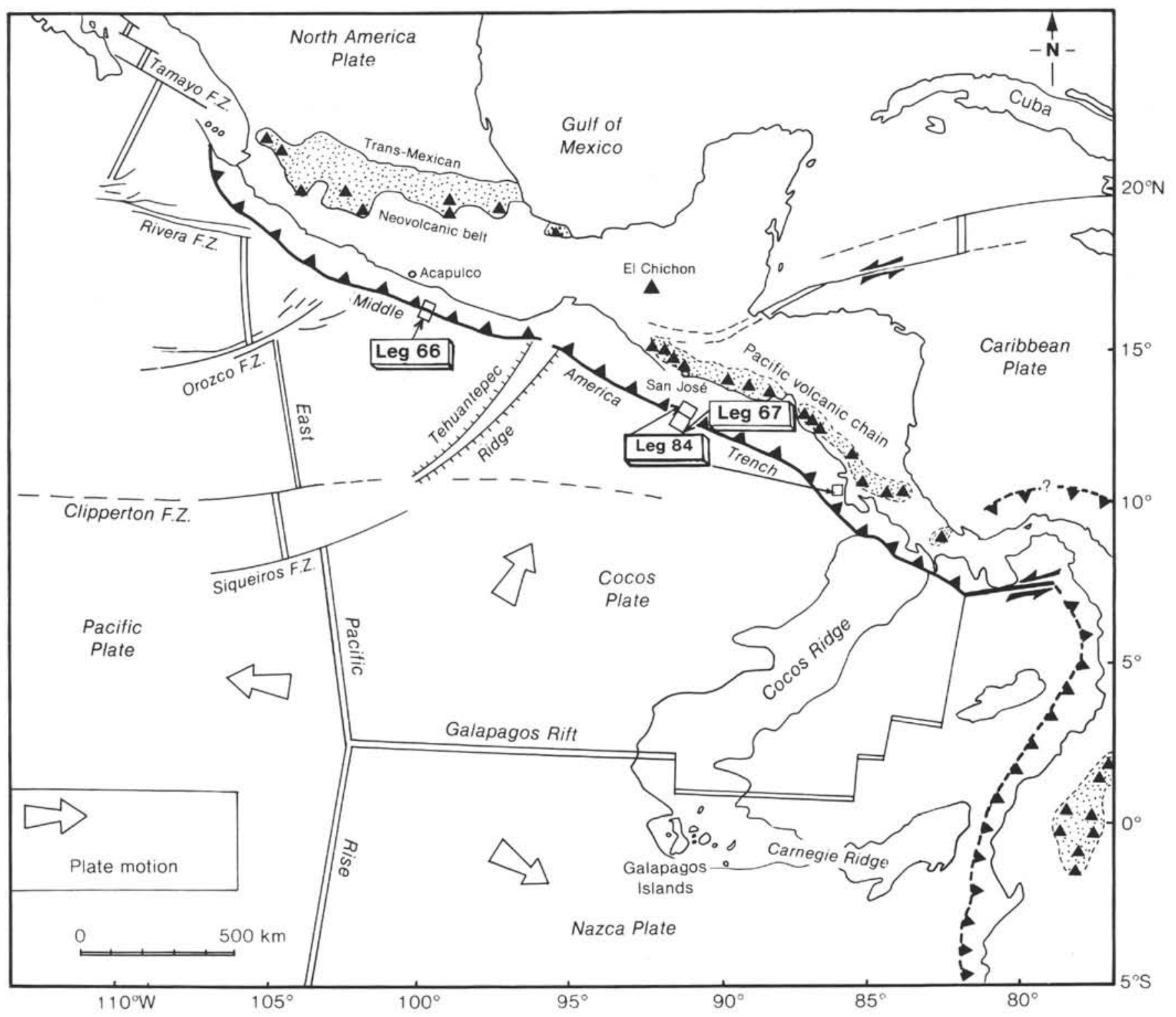

Figure 1. Major tectonic elements of Central America and the Middle America subduction zone. Leg 84 rectangle locates Guatemala transect, and small square locates Costa Rica Site 565.

largely frustrated by poor core recovery and by the unexpectedly widespread occurrence of gas hydrates in the continental margin sediments, but the evidence acquired then tantalizingly suggested there was little or no accretion in this subduction complex.

The return of the Deep Sea Drilling Project to the Middle America Trench during Leg 84 makes this active margin the most intensively drilled in the history of the Project. The leg had the same objectives as did Leg 67: to test the trench-slope accretionary model. In addition, Leg 84 was designed to sample and study the gas hydrates in the slope sediments. A final goal was to penetrate through the subduction complex to the downgoing plate. Because more drilling there is unlikely in the next several years, a summary of sedimentation across the landward slope of the Middle America Trench is appropriate at this time.

\section{Geologic Setting}

The Middle America slope sediment apron of commonly siliceous dark olive gray mud and mudstone is typical of active margins. Most clay in the sediment is smectite derived from the ash produced along the volcanic arc. Sediment accumulation rates are generally high and are punctuated by local and regional unconformities, the local ones resulting as both feeder channels of turbidites and broad mass flows shift across the continental slope. Postdepositional structures and fabrics reflect subsequent local movement and settling of the sediment as well as tectonic deformation. Swath maps and seismic records illustrate mass wasting. The physical properties of the sediment give further indication of resedimentation and erosion of the slope apron. Benthic foraminiferal assemblages locate potential sediment sources 
and may indicate the proportion of reworked rock and sediment.

Evidence of the presence of gas hydrate, an icelike combination of gas and water, is common in convergent margin settings and readily observed in the Middle America western slope. In seismic reflection records its concentrated occurrence is indicated by a bottom-simulating reflection (BSR) at the base of the gas hydrate where free gas rather than a solid form of gas fills interstices. The frequent recovery of gas hydrate in cores from the Guatemalan margin, although singular in the history of DSDP drilling, would probably have been more common had there been an equivalent number of holes at other convergent margins.

Onshore of the transect drilled across the Guatemalan margin, the geology is dominated by the Volcanic Highlands, a volcanic front of Tertiary flood basalts, rhyolites, and andesites punctuated by high-relief Quaternary basalt cones. This volcanic arc roughly parallels the trend of the Middle America Trench offshore, and partially obscures the trace of the Polochic-MotaguaChamelecon fault system, wherein Upper Cretaceous pelagic limestones overlie and are thrust over ultramafic assemblages. Upper Cretaceous limestones and ophiolitic material are juxtaposed in other areas of Central America and the Caribbean, for example, in Costa Rica adjacent to DSDP Site 565, and in Columbia (Dengo, 1972), although the nature of the juxtaposition (depositional, slumped, or tectonic contact) is not the same in all of these places.

On the seaward slope along the axis of the Middle America Trench, hemipelagic silt and clay and arc-derived turbidites are ponded on the descending ocean crust and its blanket of pelagic sediment. Silt and clay predominate over sand, and fossils displaced from the shelf and slope are common (Coulbourn et al., 1982). On the basis of lithology alone, the surficial sediment in the Trench axis and on the seaward slope is not readily distinguished from most sediment on the landward slope.

At the Middle America Trench the Cocos Plate is subducted beneath Central America. The Cocos Plate is blanketed by pelagic white foraminifer-nannoplankton chalk and red brown clays of the Miocene age overlain by Quaternary and Pliocene hemipelagic silt and clay, as well as by rare turbidites from the inner slope of the Trench. Thus the surface sediments on the Cocos Plate adjacent to the Trench are largely the distal facies of turbidites from the same sources as the thicker sediment blanket on the slope of the Guatemalan continental margin.

During Leg 84 a transect was drilled across the Guatemalan continental margin (Fig. 2). The holes provided samples of sediments and sedimentary rocks of the upper slope (Sites 568 and 570), midslope (Site 569), midslope canyon (Site 566), and lower slope (Site 567). Basement was reached and sampled at several sites (Sites 566, 567,569 , and 570). Four sites were drilled into slope sediment on Leg 67, providing a total of nine Guatemalan slope sites (Fig. 3). In addition, a single hole was drilled into midslope sediment on the landward slope of the Trench off Costa Rica (Site 565) in an attempt to study the age and origin of basement and the development of gas hydrate.

\section{Reworked Hemipelagic Sediment of the Costa Rica Continental Margin Midslope (Site 565)}

Site 565 is located between two submarine canyons on the Costa Rican margin about $20 \mathrm{~km}$ landward of the Middle America Trench axis and $1700 \mathrm{~m}$ above it at a depth of about $3100 \mathrm{~m}$. A single hole was drilled to $328 \mathrm{~m}$ (34 cores) with nearly $90 \%$ recovery; except for a small piece of limestone in the core catcher of the last core (563-34), the entire $328 \mathrm{~m}$ belongs to the same lithologic unit.

The sediment consists of generally uniform, massive upper Pleistocene to lower Pliocene dark olive gray to dark green gray mud and mudstone. The mud is predominantly clay (mostly smectitic) with minor amounts of quartz, mica, and plagioclase feldspar. Volcanic shards are dispersed throughout the section, and two sandy layers in Cores 565-21 and -33,CC are tuffaceous with angular clasts of quartz, feldspar, minor hornblende, augite, K-spar, zircon, apatite, and authigenic pyrite or marcasite (Helm, this volume).

Sedimentary structures are rare, only subtly visible macroscopically, and less common in the upper part of the section; these structures are graded silt beds up to $2 \mathrm{~cm}$ thick (Cores 565-4, -5 , and -9 ), silty laminae (Core 565-5), and small clasts of slightly more lithified mudstone of the same composition as the surrounding matrix. Yellowish mottling and a slightly calcareous composition grade downsection into more clearly defined and rare cemented burrows. Nannoplankton and foraminifers are rare to common and are of mediocre to good preservation.

Scaliness throughout the section is attributed to reworking of the slope sediment during downslope creep (Fig. 4). Scanning electron microscope (SEM) studies revealed that the microscaly fabric reflected microscopic layers of clay smeared together with other sediment constituents. Over half the benthic foraminiferal assemblage in the section has been transported downslope from shallower settings (Baltuck et al., this volume). Reworked Cretaceous nannofossils below Core 565-29 further indicate redeposition from a Cretaceous source during latest Miocene or early Pliocene. Physical properties such as porosity, density, and water content show trends toward a greater degree of consolidation to a depth of 45 to $50 \mathrm{~m}$, below which these properties are fairly uniform (Taylor and Bryant, this volume). Seismic profiles of the Costa Rican slope show that the slope sediment lacks acoustically distinct coherent bedding (Shipley et al., 1982). Baltuck et al. (this volume) concluded from these data that continuous downslope creep, particularly in the upper few tens of meters of the sediment column, was a significant mode of sediment transport on the continental slope.

Sediment accumulation rates are high through most of the cored interval: $165 \mathrm{~m} / \mathrm{m}$.y. from 0 to $80 \mathrm{~m}$ subbottom depth; $13 \mathrm{~m} / \mathrm{m}$.y. from 80 to $90 \mathrm{~m}$; and $123 \mathrm{~m} /$ m.y. from 90 to $328 \mathrm{~m}$. The change in sedimentation rate from 80 to $90 \mathrm{~m}$ suggests an unconformity at this 


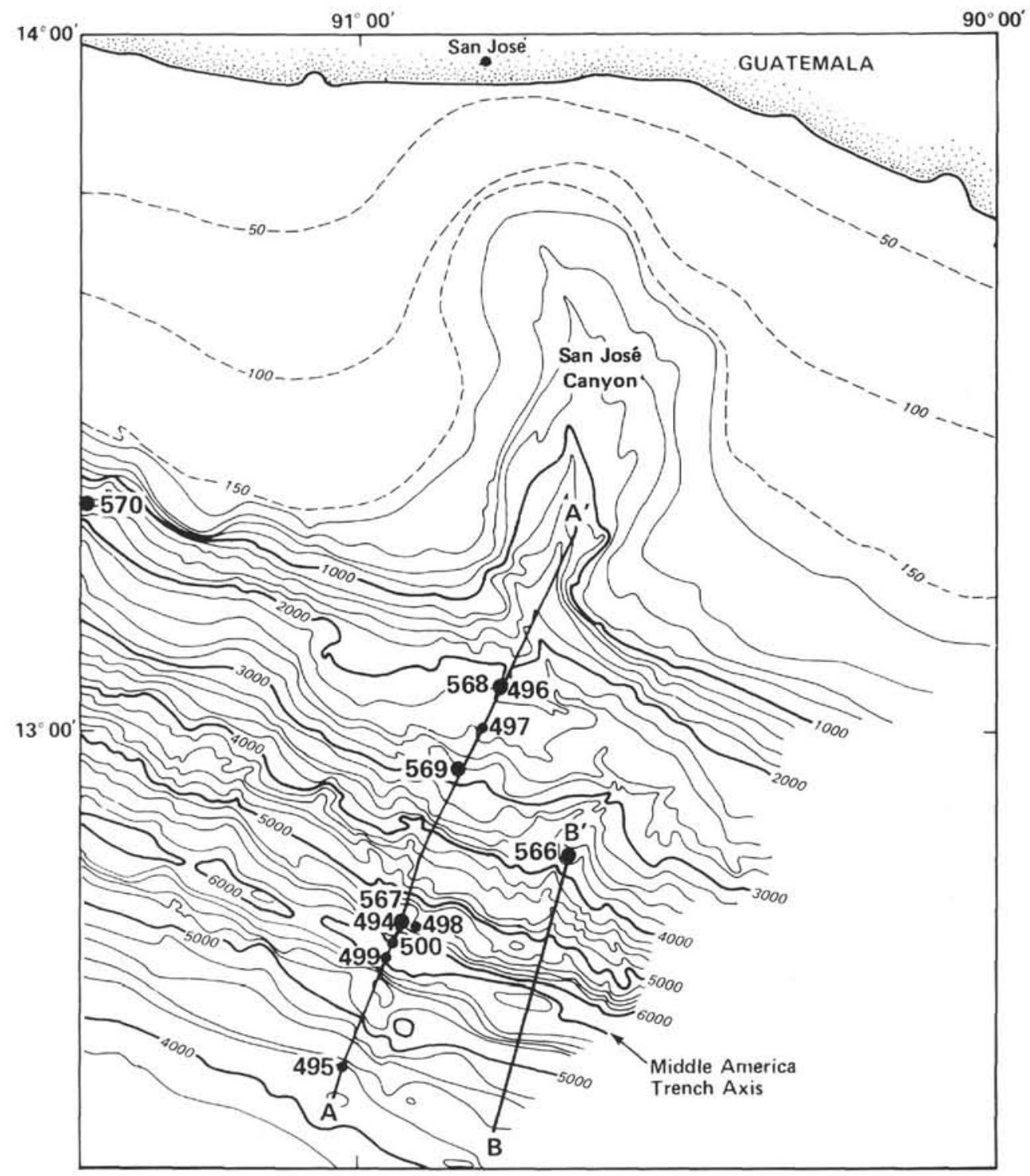

Figure 2. Bathymetry of the Guatemalan margin and San José Canyon showing the UTMSI (University of Texas Marine Sciences Institute) survey tracks $\left(A-A^{\prime}, B_{-1}\right)$ and the locations of Legs 67 and 84 sites drilled off Guatemala.

interval. Ecologic analysis based on benthic foraminiferal assemblages indicates a gradual uplift from abyssal depths greater than $3500 \mathrm{~m}$ in the early Pliocene to late Miocene to lower middle bathyal depths $(2000 \mathrm{~m})$ in the late Pleistocene, and then subsidence to the present depth of $3100 \mathrm{~m}$ (McDougall, this volume).

Gas hydrate was recovered at Site 565 (Cores 565-30 and -33). Degassing voids occur in the sediment below Core 565-30, gas was detected in sediment below about $175 \mathrm{~m}$, and an unusually high proportion of lighter alkanes and lack of heavier hydrocarbons in the gases were detected in the sediment.

The high crystallinity of smectite crystals in even the upper part of the sediment column suggests a detrital rather than diagenetic origin for much of this mineral (Helm, this volume), which is corroborated by the presence of fresh volcanic shards and mafic minerals throughout the length of the hole. The zeolites heulandite and analcime are present although in very minor amounts, and authigenic pyrite or marcasite is common from Cores 565-24 to -34 .

Drilling at Site 565 halted when the pipe began to stick and the hole to collapse. The bottom of the hole was no older than possibly late Miocene. Thus our major objective of relating offshore geology to the complex onshore geology of the Nicoya Peninsula was thwarted well above basement. Nevertheless, the extensive evidence of redeposition and reworking of sediments and microfossils was an introduction to Central American slope sedimentary processes that we would further observe in subsequent sites off Guatemala.

\section{Upper Slope Hemipelagics and Turbidites on the Guatemalan Continental Margin (Site 570)}

Site 570 is located on the edge of a small bench on the upper slope of the Guatemalan margin at a depth of about $1700 \mathrm{~m}, 40 \mathrm{~km}$ landward of the Middle America Trench (Fig. 5). 
The site is located in an area of high-amplitude magnetic anomalies unique to this region in the slope; the magnetic field is featureless downslope until close to the Trench axis. The band of anomalies has been interpreted as the truncated end of an igneous oceanic basement beneath forearc basin sediment (Seely et al., 1974; Ladd et al., 1982; Ibrahim et al., 1979), and the objective at Site 570 was to sample acoustic basement in an area where sediment cover is thin, where the magnetic anomaly is high-amplitude, and where initial sediment to overlie basement could be recovered. Subsequent sedimentary history would help reconstruct the Cenozoic tectonic history of the present Guatemalan convergent margin.

Many small canyons begin or end in the upper and midslope region of the Guatemalan margin, suggesting shifting depocenters and sites of erosion (Volpe et al., this volume). The lithologic units recovered at this site are subdivided on the basis of lithology, age, and degree of lithification. The hole was drilled with $41 \%$ recovery to a sub-bottom depth of $402 \mathrm{~m}$ (42 cores), reaching serpentinite basement at $363 \mathrm{~m}$.

The uppermost Units I and II (Cores 1-27; 0-255 m sub-bottom) are Recent to Pliocene olive gray to greenish gray massive mud and mudstone. Siliceous biogenic remains (mostly diatoms) and calcareous biogenic remains (foraminifers and nannofossils) together constitute up to $13 \%$ of the sediment; their preservation is variable. Sedimentary structures are not common, comprising mostly graded bedding and some silty laminae. The coarser basal layers of these graded beds contain up to $15 \%$ foraminifers and grains of feldspar and volcanic shards (Fig. 6). Several of these layers contain rounded pebbles of pumice. Ash layers are fairly common throughout the entire section, and many provide the porosity for accumulations of gas hydrate.

Two hiatuses separate Unit III (Cores 27-35; 255-330 m sub-bottom, lower to upper Miocene) from Units II and IV. Unit III is lithologically similar to Units I and II but includes the coarsest sand recovered during Leg 84 . That sand is underlain by a conglomerate layer containing large clasts of andesite and limestone. Unit III displays fractures that are described in detail in the section on Site 568, and scaly fabric, which is described in the Site 565 section.

Recovery was poor in Unit IV (Cores 35-39; 330-374 m sub-bottom), and the complex stratigraphy of the lower Eocene was reconstructed with the aid of downhole logs. In Cores 35 and 36 silty mud of several meters' thickness is underlain by dark greenish gray to olive black sand rich in plagioclase. Below this sand is a clayey nannofossil limestone with minor quartz and feldspar (Core 37). About $2 \mathrm{~m}$ of mud are inferred from logs and mud traces between the limestone and the layer below, a very coarse sand (Core 37). The sand overlies yet another limestone (Core 38 ), which in turn overlies a radiolarian-rich dark mudstone containing dispersed clasts of limestone, pumice, and cemented sandstone (Core 38). A basal conglomerate with a coarse calcareous-cemented sandstone matrix underlies this and rests directly on serpentinite basement (Core 39).
Benthic foraminiferal assemblages indicate a gradual shallowing from abyssal depths in early Eocene through Pliocene to upper middle bathyal depths by late Pleistocene (McDougall, this volume). A similar shallowing trend was observed at the ESSO Petrel Well, $40 \mathrm{~km}$ away at the edge of the shelf, although the shallowing was rapid in late Paleocene and early Eocene and more gradual in the late Cenozoic (Seely, 1979).

The occurrence of dolomite at this site (Core 27) was unexpected. About $15 \mathrm{~cm}$ of highly fractured, well-indurated micritic dolomite containing grains of quartz and feldspar is veined by calcite. Gas hydrate filled fractures in the dolomite. Immediately below this layer, a spectacular 1.3-m-long core (Core 27) of massive hydrate was recovered at about $250 \mathrm{~m}$ sub-bottom. Downhole logs indicate that the hydrate is $4 \mathrm{~m}$ thick and local hydrate filling fractures extend to the serpentinitic basement.

The silica in radiolarian-rich sediments from the lower Eocene base at Site 570 consists of opal-A, opal-CT, and chalcedony. Pore waters from the cores are oversaturated with respect to quartz, although less so toward the base of the hole. Authigenic chalcedony fills radiolarian tests. Plagioclase feldspar and volcanic glass are the most common detrital components of the sediment besides smectite; plagioclase ranges in composition from andesine to labradorite, as determined by optical methods. The $\mathrm{Mg}-\mathrm{Al}$ carbonate hydrotalcite was found in detrital serpentinitic sediments. Calcium carbonate occurs mostly in redeposited nannofossil limestone clasts. $\mathrm{Cu}-$ bic crystals of authigenic pyrite occur in the basal Eocene sediments (Core 570-38), and clinoptilolite occurs filling radiolarian tests, as isolated crystals, as fissure fill, and replacing smectite (Helm, this volume). Helm (this volume) suggests that the clinoptilolite is derived from kaolinite, which decreases in concentration downhole. Analcime occurs as a secondary fill in some fissures.

A high amount of $\mathrm{Cr}$ and $\mathrm{Ni}$ in the lower Eocene sediment at Site $\mathbf{5 7 0}$ may reflect an admixture of ultramafic minerals, although detrital serpentine was not detected in the fine-grained sediments at Site 570.

\section{Turbidites and Hemipelagic Sediment of the Upper Slope off Guatemala (Site 568)}

Site 568 is located at a water depth of about $2030 \mathrm{~m}$, approximately $38 \mathrm{~km}$ from the coast of Guatemala (Fig. 2 ), and roughly a kilometer upslope of Site 496, which was abandoned during Leg 67 after gas of possible thermogenic origin and possible hydrate composition was encountered. The major objective at Site 568 was a detailed monitoring of gas throughout the section to study the formation of gas hydrate.

Forty-five cores were drilled with about $74 \%$ recovery to a sub-bottom depth of $418 \mathrm{~m}$; the oldest sediment recovered is early Miocene or possibly late Oligocene with reworked Eocene clasts. The hole was terminated just above the base of hydrate reflection for safety reasons.

The slope sediments are similar in composition to the mud and mudstones recovered at Site 570. Two lithologic units are distinguished on the basis of differences in age, color, degree of induration; in addition, Unit I (Cores 
TRENCH

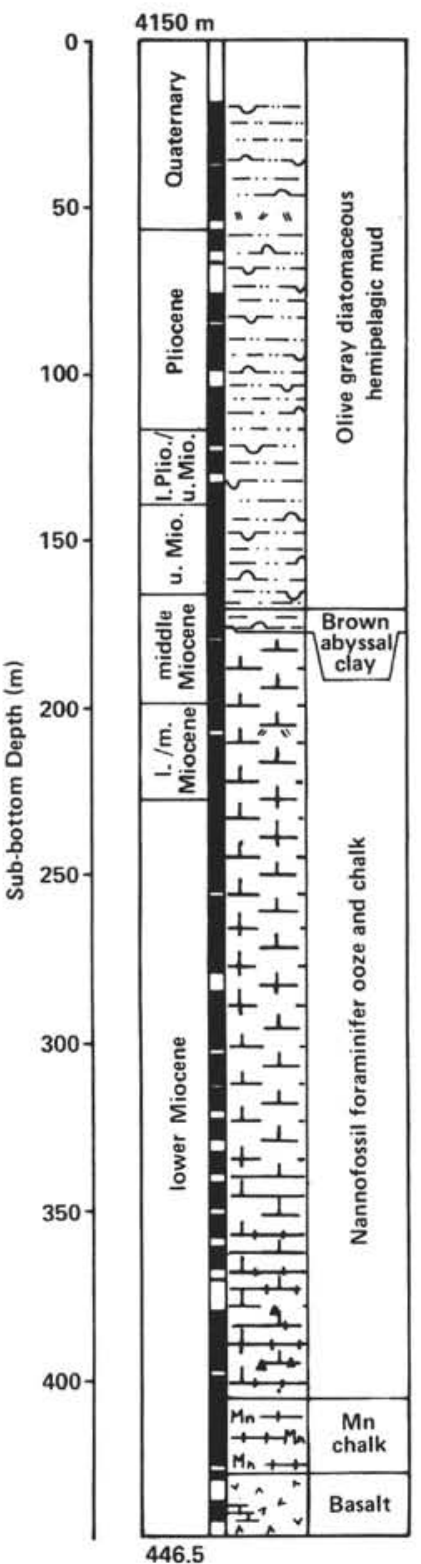

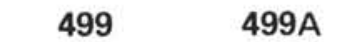

6127

500

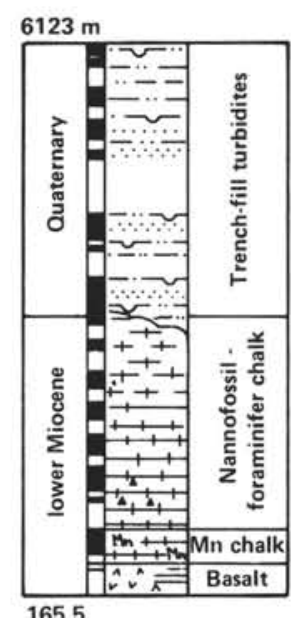

of \begin{tabular}{ll} 
u.Plio $=-1$ & $\begin{array}{l}\text { (u. Miocene- } \\
\text { ?. Pliocene) }\end{array}$ \\
\hline
\end{tabular}

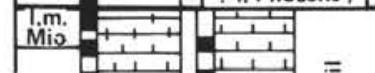

年

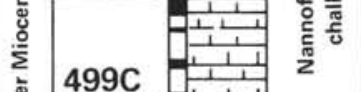
120.0

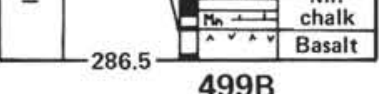

$499 \mathrm{~B}$
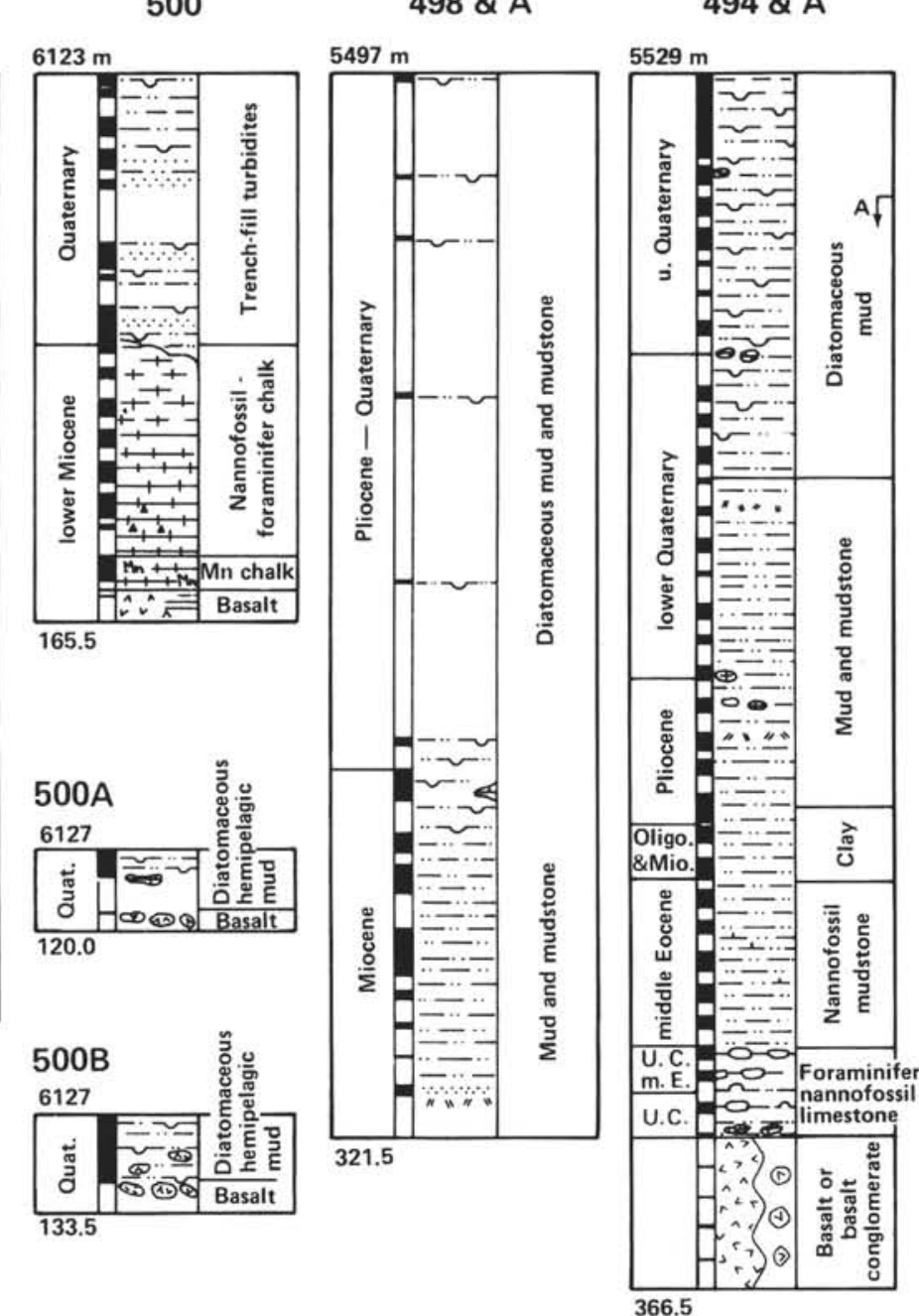

497

496
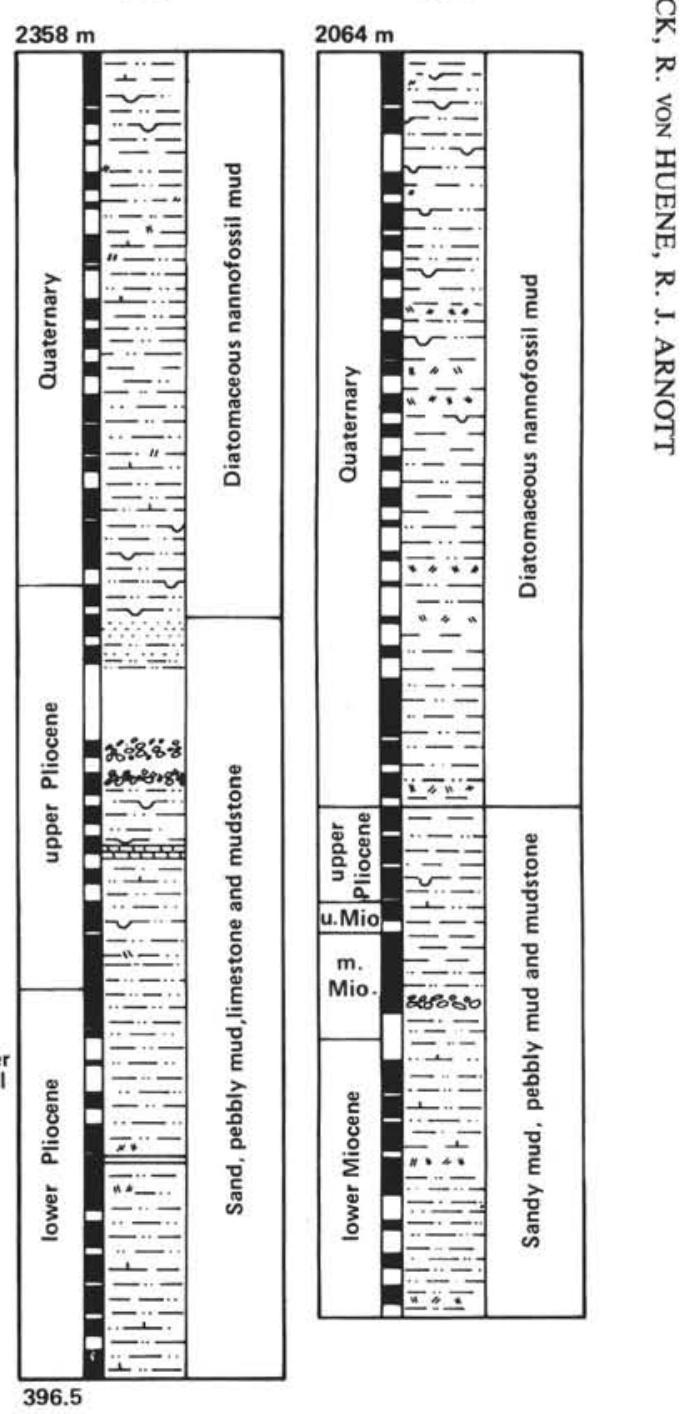
B

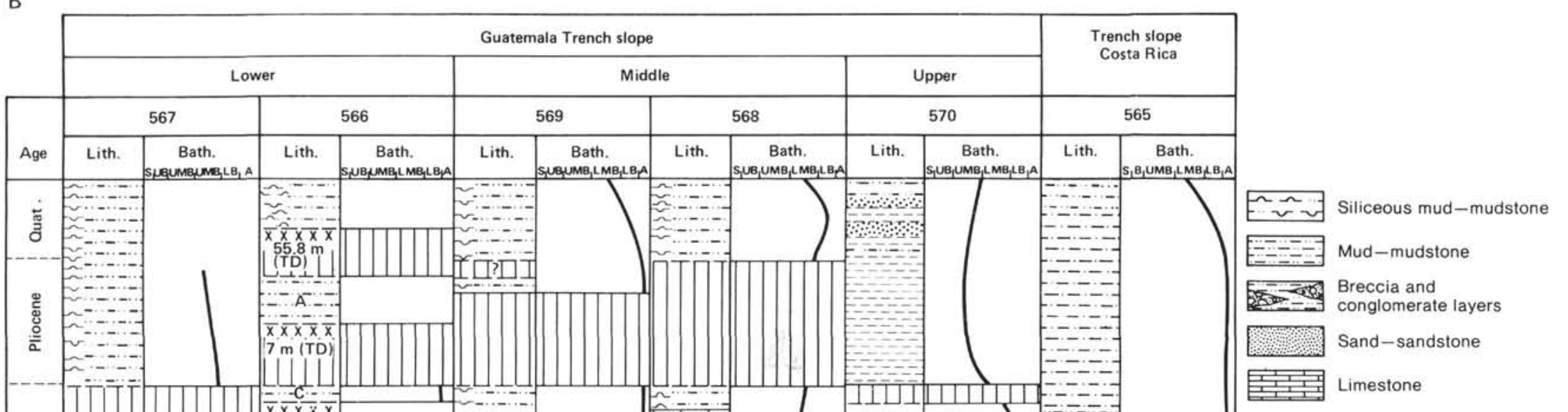

Hemipelagic mud with - $\sim$ siliceous biogenic admixture Brown abyssal clay 


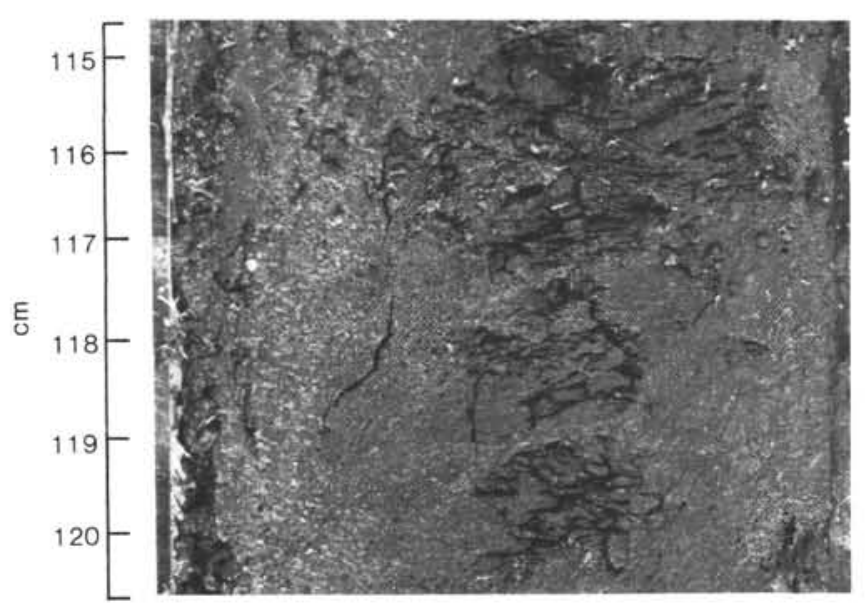

Figure 4. Typical scaly fabric observed at Site 565: Sample 565-16-4, $115-120 \mathrm{~cm}$ (from Baltuck et al., this volume).

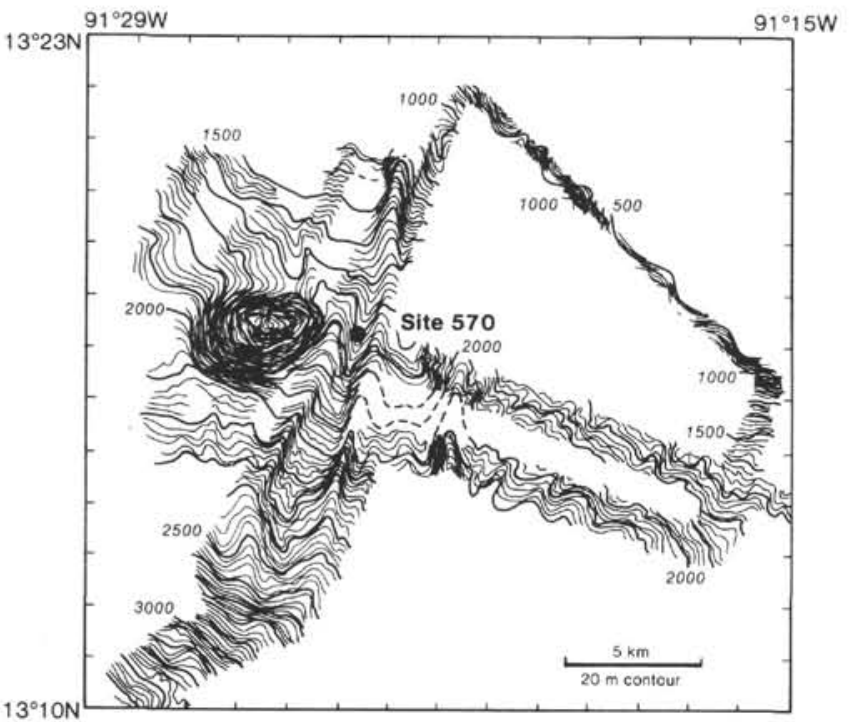

Figure 5. Seabeam bathymetry of seafloor in the area of Site 570 (from Volpe et al., this volume).

$1-20 ; 0-182 \mathrm{~m}$ sub-bottom) has a slightly finer texture. The textural contrast is observed best across the hiatus at the base of Unit I between the middle and upper Pleistocene sediments (base of Core 2 to $44,182-418 \mathrm{~m}$ sub-bottom).

Unit $\mathrm{I}$ is a siliceous mud and mudstone, massive and easily deformed by drilling, containing up to $15 \%$ siliceous biogenic skeletons. Unit II displays mottling and burrowing, possibly because it is more indurated and thus less homogenized by drilling. Unit II also contains much siliceous material, several layers of slightly calcareous mudstone, nannofossil-rich mud, limestones, and one limestone conglomerate layer; limestone clasts are widely dispersed throughout the unit. Clasts of pyritized radiolarian-rich Eocene mudstone occur in the Miocene mudstone at the bottom of the hole.

As at Site 570 to the northwest, a remarkable feature of the slope sediment in the region is the variability of thickness of sections: Site 568 and Leg 67 Sites 496 and

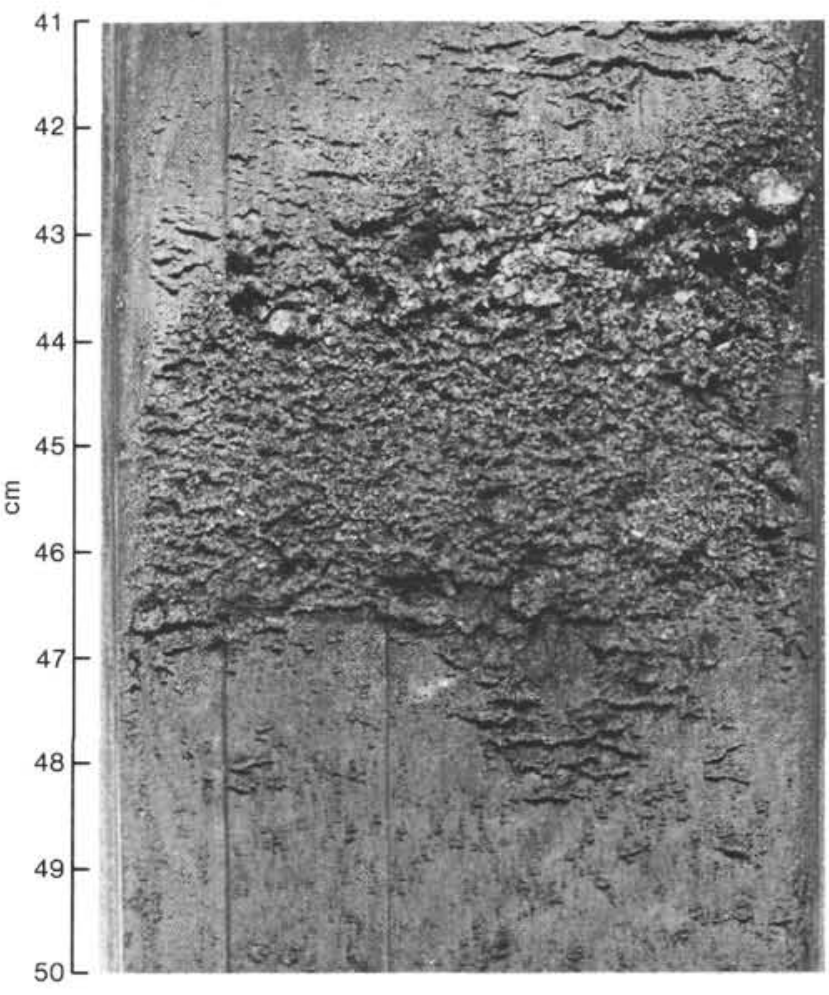

Figure 6. Graded sandstone bed, Sample 570-2-5, 41-50 cm, showing angular volcanic ash and lithic fragments.

497 are within about $10 \mathrm{~km}$ of each other, but there is a thickness difference in their Pliocene-Pleistocene sections of nearly $200 \mathrm{~m}$. Seismic surveys in this area show considerable relief of the acoustic basement but drilling was halted above the sediment basement unconformity so the basement composition here is unknown (von Huene et al., this volume).

Seismic records show large-scale (50-200-m-thick) lobes of sediment prograding downslope and probably subject to the same slow, nonepisodic plastic creep evident at Site 565 off Costa Rica where scaly fabric characterizes lobe sediment. The apparent dip of bedding at Site 568 increases from horizontal through locally 60 or $70^{\circ}$ between 263 and $408 \mathrm{~m}$ sub-bottom (Cores 29-43). The local nature of these dips is inferred from the clear reflections in seismic records that dip only $5^{\circ}$ : the large-scale $5^{\circ}$ dipping stratification must contain areas of 60 to $70^{\circ}$ dipping beds possibly localized at the front of the sediment lobe.

Another significant feature of sediment deformation at Site 568 and also at Site 569 are dewatering veinlets. Offset can be observed along some of these. The veins are also described in detail for Sites $67-496$ and -497 (Cowan, 1982) as well as off the coasts of Oregon and Japan (Carson, 1977; Carson et al., 1982). Veining style is either anastomosing networks of small veins or a series of subparallel planar to sigmoidal veins (Fig. 7). They are extensional fractures that formed perpendicular to the minimal principle compressive stress axis $\left(\sigma_{3}\right)$ (Ogawa and Miyata, this volume), and contain the same minerals (smectite and minor kaolinite) as the surrounding sediment in a microfabric of closely packed aggre- 


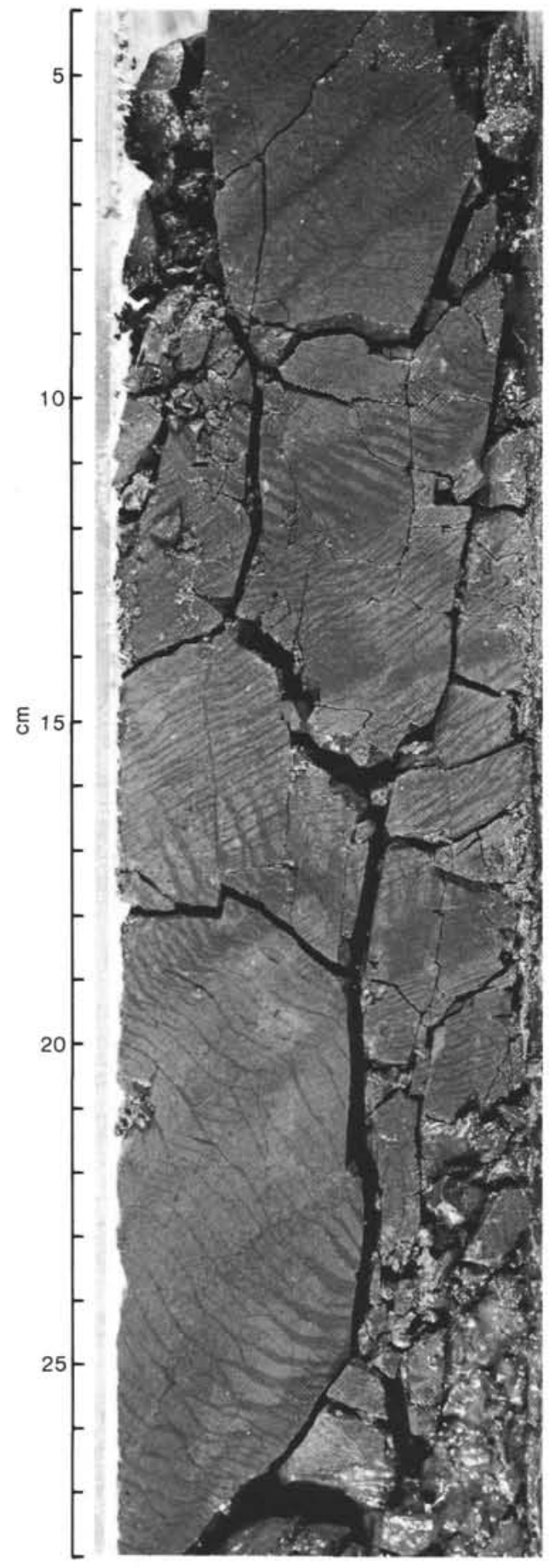

Figure 7. Subparallel and anastanosing veins in mudstone; the interval illustrated is Sample 569-15-1, 4-28 cm. Offset of host sediment along veins is also observed in sediments from Sites 568 and 569.

gates of clay flakes oriented parallel to the vein boundaries (Volbrecht and Helm, this volume).

The paleobathymetry of Site 568 based on benthic foraminiferal assemblages is complex (McDougall, this volume). The oldest sediment (mid-Miocene to late Oligocene; Cores 42-44) was deposited at abyssal depths (sub-CCD-carbonate compensation depth), whereas sedimentation depths at Cores 568-41 to -21 began at upper middle bathyal depths and deepened to lower bathyal ranges. Pleistocene sedimentation (Cores 19-17) occurred at lower middle bathyal depths, and at lesser depths upsection. Between Cores 7 and 6, paleodepth shows rapid increase to abyssal levels that are maintained to Core 2 . Core 1 contains fauna indicative of depths between the present lower bathyal setting and the abyssal depths of Core 2.

Although Site 568 was selected to investigate gas hydrates, their occurrence there was not spectacular. Their presence was indicated by degassing voids, by the disrupted sediments between 190 and $345 \mathrm{~m}$ sub-bottom, and by the low values of chlorinity and salinity in sediment pore waters (Kvenvolden, this volume; Hesse et al., this volume). Solid hydrate was recovered filling the fractures of a tuffaceous mudstone at about $403 \mathrm{~m}$ depth.

\section{Turbidites and Hemipelagic Sediment of the Midslope} Continental Margin off Guatemala (Site 569)

Site 569 lies between Sites 568 and 567 at a depth of about $2800 \mathrm{~m}, 27 \mathrm{~km}$ landward of the Trench axis (Fig. 2). Two holes were drilled at this site to a total sub-bottom depth of $364 \mathrm{~m}$. The oldest sediment recovered was early(?) Eocene. The objective at this site was to sample the basement and the sediment immediately overlying it to study the tectonic history of the midslope area.

The slope sediments are similar to those at Site 568: a Recent to upper Pliocene assemblage of siliceous dark olive gray mud and mudstone with ash layers (Unit I, Cores 1-7; 0-57 m sub-bottom) is separated by an unconformity from Miocene to lower Oligocene mudstone containing burrows, veining, fractures, microscaly fabric, and beds of increasing dip downhole (Unit II, Hole 569, Cores 7-27, 50-250 m sub-bottom and Hole 569A, Cores 1-8, 246-332 m sub-bottom). Oligocene ash layers indicate that island-arc volcanism and subduction began at least that early; minor ash also occurs in Eocene sediment. An unconformity separates the Oligocene from the lowermost sedimentary Unit III, a heavily mottled and bioturbated radiolarian-rich blue gray Eocene mudstone (Core 569A-9, 322-352 m sub-bottom). The lowermost $30 \mathrm{~cm}$ of the section consist of a mottled brownish black mudstone; this rests on a basement of metagabbro and metabasalt.

Benthic foraminiferal assemblages indicate deposition at abyssal depths below the CCD from the Eocene to the Pleistocene, with the depth shallowing to the present lower bathyal zone in latest Pleistocene (McDougall, this volume). Hiatuses occur between the Pleistocene and mid-Miocene, between upper Oligocene and upper Eocene, and between the upper Eocene and lower early middle-upper lower Eocene.

The upper $30 \mathrm{~m}$ of core at Site 569 had gas expansion cracks and smelled strongly of $\mathrm{H}_{2} \mathrm{~S}$ upon core splitting. Gas hydrate could have been present at greater depth, as indicated by a decrease in chlorinity and salinity with depth and lack of hydrocarbons larger than butane, but there was no visual evidence of hydrate at this site.

\section{Sediments of the San José Canyon (Site 566)}

This site, located in the broad valley of the San José Canyon at a depth of about $3700 \mathrm{~m}$, and $22 \mathrm{~km}$ from the Trench axis, was chosen for its thin sediment cover 
over acoustic basement. Of the four holes drilled to find the age and lithology of sediment on basement, three reached the basement objective; there was no recovery in Hole 566B.

Hole 566 was cored continuously through $31 \mathrm{~m}$ of sediment to serpentinite basement. The upper $26 \mathrm{~m}$ (Unit I, Cores 1-5) are relatively uniform Recent to upper Pleistocene dark olive gray siliceous mud with common silty laminae, silty graded beds, and a few sandy mud layers. The composition of the mud is predominantly smectite with feldspar and quartz grains and minor detrital carbonate. Calcareous microfossils are few and poorly preserved. Dispersed mud pebbles of the same composition as the matrix occur throughout the unit.

A 3-m-thick upper Pleistocene breccia with a calcareous dolomitic matrix underlies the mud (Unit II, Core 5, 26-24 m sub-bottom). The breccia contains clasts of tuff up to $3 \mathrm{~cm}$ in diameter and directly overlies serpentinite basement.

At Hole 566A ( $3865 \mathrm{~m}$ water depth) only about $6 \mathrm{~m}$ of massive upper Pliocene mud (Unit I, Core 1, 0-6 m sub-bottom) of the same composition as at Hole 566 overlies serpentinite. At Hole 566C (3675 m water depth) the first $49 \mathrm{~m}$ sub-bottom were washed down and after coring, washing continued from 88 to $109 \mathrm{~m}$. The interval from 49 to $88 \mathrm{~m}$ contains Pleistocene to upper Miocene massive dark olive gray mud. The wash core and cores below $109 \mathrm{~m}$ contain about equal amounts of sandstone and mudstone fragments (Unit II, Core H2, about $50-110 \mathrm{~m}$ sub-bottom). The sandstone provenance will be discussed in a later section; sandstone is derived from Tertiary and Quaternary igneous rocks.

Alteration of volcanic glass to a network of acicular clays or zeolites (clinoptilolite and analcime) is more common with increasing depth, and mafic grains replaced by clay are common. Euhedral pyrite crystals occur in clay groundmass, particularly in the breccia matrix above basement in Hole 566C (Helm, this volume). Calcite replacement of grains and matrix is observed in the sandstones of Hole $566 \mathrm{C}$, whereas the authigenic dolomite and a member of the pyraurite-hydrotalcite group that occur in weathered serpentinite of Holes 566 and 566C are probably related to the increase in $\mathrm{Mg}$ concentration in the pore waters of a weathering serpentinite (Helm, this volume).

Two modes of deposition are indicated by sedimentary features of the holes in a valley of San José Canyon. Massive mud with a scaly texture is similar to the muds from intracanyon settings. Consolidated sediment near the surface (Taylor and Bryant, this volume), a basement of high relief in contact with sediment of various ages from Pleistocene to Miocene, and layers of coarse and graded sediment indicate periodic sedimentation and erosion by turbidity currents in the Canyon and even high along the Canyon walls.

Here as at all sites on the Guatemalan slope more than half of the individuals in benthic foraminiferal assemblages are from the upper and middle slope. A few reworked Cretaceous nannofossils were identified from Holes 566 and 566C. Ecologic analysis of benthic foraminifers indicates that sedimentation was at lower ba- thyal to abyssal depths, shallowing by late Pleistocene to the present lower bathyal setting (McDougall, this volume).

A surprising development in the hydrate study was the vigorous degassing observed from fractured serpentinite in Core 566C-6. Despite problems with air contamination, analyses indicated that the sample contained $49 \%$ methane with significant amounts of ethane, propane, isobutane, and higher molecular weight hydrocarbon gases, suggesting a thermogenic origin. The exponential decrease in concentration of alkane gases higher than isobutane at Core 566C-7 suggests that the gases may have been present as gas hydrates (Kvenvolden, this volume).

\section{Turbiditic, Hemipelagic, and Pelagic Sediments at the Foot of the Slope off Guatemala (Site 567)}

Site 567 at the base of the lower slope off Guatemala is located about $1.5 \mathrm{~km}$ north of the Trench axis and within $100 \mathrm{~m}$ of Leg 67 Site 494 in water about $5530 \mathrm{~m}$ deep (Fig. 2). This site was partially drilled on Leg 67 (Site 494). The major objective here was to sample below the slope deposits. It had been predicted from geophysical data that the material underlying slope sediments would be an imbricate series of Pleistocene trench deposits, but during Leg 67 a normally ordered stratigraphic sequence from Upper Cretaceous to Quaternary was found. Site 567 was designed to finish drilling through the slope deposits and underlying sedimentary section into basement and the subducting Cocos Plate.

The Pleistocene to Pliocene (Unit I, Hole 567, Cores $\mathrm{H} 1$, and 1-2 and Hole 567A, Cores H1, and 1-3, 176$215 \mathrm{~m}$ sub-bottom) is similar to the slope sediments described at sites farther up the slope; that is, it is a generally massive dark olive gray to grayish olive green siliceous mud. Sand is present in graded beds up to $5 \mathrm{~cm}$ thick in Core $567 \mathrm{~A}-2$, some laminations occur in Core 567A-3, and small, subrounded to subangular clasts of bluish gray mud (probably containing serpentine) occur in Cores $567 \mathrm{~A}-1$ and -2 .

An unconformity separates these from the next unit, a lower Miocene grayish olive green to dusky yellowish green mud that forms a matrix for sedimentary breccia and boulders in its lower part (Unit II, Cores 567A-3 to $-18,215-359 \mathrm{~m}$ sub-bottom). The breccia clasts are mostly about $1 \mathrm{~cm}$ in diameter but range from $3 \mathrm{~mm}$ to $50 \mathrm{~cm}$. They include pieces of pumice, Miocene to Eocene mudstone clasts, light gray Eocene limestone, light greenish gray nannofossil ooze, sandstone, bluish gray Cretaceous limestone, and serpentinite.

Ash layers in Cores 567A-6 and -8 are both graded, indicating deposition by current transport rather than air fall. A dusky blue mud composed mostly of weathered serpentinite $(80 \%)$ and dolomite $(15 \%)$ and fresher clasts of dolomite occurs in Core 567A-7. Four cores (Cores 567A-14-18) contain serpentinite. Below Eocene and Miocene mud, serpentinite was again recovered in Core $567 \mathrm{~A}-18$. The serpentinite is locally altered to a serpentinitic mud.

In the next core (Core 567A-19), a pale red to pale greenish yellow micritic Campanian limestone was re- 
covered. It is fractured and heavily veined with calcite. Below this core only altered mafic and ultramafic igneous rocks of Central American basement were recovered.

The nature of the contact between these few meters of limestone and the serpentinite below is unclear; it could be tectonic or depositional. The limestone is similar to descriptions of the Sabana Grande pelagic limestone associated with the ophiolitic suite in Costa Rica (Azéma et al., this volume); it is also similar to the Upper Cretaceous limestone associated with ophiolite in the Central Cordillera of Guatemala along the PolochicMotagua fault zone (Rosenfeld, 1981). By analogy with the onland associations of limestone and ophiolite it was probably emplaced on the slope during the same tectonism that emplaced the ultramafic rocks.

The Eocene and Cretaceous clasts in Miocene sediment indicate Érosion and transport from outcrops of this age upslope. The four cores of serpentinite suggest slumping of serpentinite blocks from upslope during the Miocene. Eocene sediment overlies basement only $100 \mathrm{~m}$ away at Site 494 and at two sites drilled on Leg 84 (Sites 569 and 570).

The Neogene mud is composed predominantly of smectites with plagioclase (mostly andesine), quartz, hornblende, and volcanic glass (Helm, this volume). Originally biogenic silica is present as opal A and opal-CT. Authigenic pyrite occurs throughout the mud at Site 567, as amorphous $\mathrm{FeS}_{2}$ down to $567 \mathrm{~A}-17$, and with cubic habit in muds below. The weathered bluish mud in Cores 567A-2, -3 , and -5 contains mostly smectite, but smear slides reveal the presence of serpentine as well, probably giving rise to the blue tint. Bright blue mud in Core 567A-7 contains mostly serpentine and a carbonate from the hydrotalcite group. In X-ray diffractograms this serpentine looks the same as that from fresh black serpentinite, so the striking color of the mud is probably a function of physical properties such as water content.

Clinoptilolite and analcime occur in the sediments below, and a white mud from Core 567A-23 contains talc, serpentine, and possibly chlorite, probably alteration products of the serpentinite. Other white muds from Cores 567A-17, -18 , and -24 contain large amounts of volcanic glass, zeolites, and apatite. Celadonite occurs in a hyalophitic basalt (567A-25). Dolomitized foraminifers are dispersed in micritic dolomite in Sample 567A$5-3,107-108 \mathrm{~cm}$. Clinoptilolite and chalcedony with high $\mathrm{Mg}$ content fill some of the foraminifer tests in the Cretaceous limestone of Core 567A-19, suggesting an association with the ophiolite involving derivation of $\mathrm{Mg}$ from alteration of these igneous rocks (Helm, this volume). Chlorite in the basal sediments is presumably due to alteration of serpentinitic rocks.

Benthic foraminifer assemblages indicate deposition at abyssal depths near or below $4000 \mathrm{~m}$ throughout the fossiliferous portion of the Tertiary section. The Cretaceous fauna suggest deposition occurred above the nannofossil CCD. Sedimentation rates vary at Site 567, ranging from $40 \mathrm{~m} / \mathrm{m} . \mathrm{y}$. during the Quaternary, $8 \mathrm{~m} / \mathrm{m} . \mathrm{y}$. during the Pliocene (possible unconformity), and $76 \mathrm{~m} /$ m.y. during the assumed early Miocene.

\section{Provenance of Sandstones from Leg 84 Sites}

Most of the clastic slope sediment of Guatemala and Costa Rican cores is composed of massive dark greenish gray hemipelagic mud with postdepositional features such as the scaly fabric and veins described earlier. An analysis of 63 samples of sand mostly from the Neogene and Quaternary turbidite layers of Leg 84 sites was made in order to identify the provenance of these sediments. Samples range in age from early Miocene to Pleistocene. The sand samples were dried in a warm oven, covered with water, and soaked to disaggregate them. Samples were then washed in a 250 -mesh sieve to remove the claysized fraction. The prepared sand samples were mixed with epoxy and allowed to harden, forming artificial sandstone chips. From these, thin sections were prepared and stained for plagioclase feldspar. The petrographic counting techniques used follow those of Dickinson (1970), Ingersoll (1978), and Watson (1981). Because the "sandstone" samples are artificial, no counts were made on interstitial material or on incompletely disaggregated clumps. Skeletal debris was included in the counts.

The "light-mineral" fraction of the sands from Leg 84 sites is dominantly composed of volcanic glass and plagioclase feldspar (Table 1, Fig. 8). Potash feldspar is present in minor amounts in some samples. Glauconite, biotite, and quartz occur in very minor amounts.

Volcanic glass and plagioclase feldspar occur in varying proportions and constitute about $90 \%$ of the lightmineral assemblage of sands recovered from the lower slope off Guatemala confirming the results of Prasad and Hesse (1982). Plagioclase grains frequently exhibit oscillatory zonation with occasional unconformities between successive growth zones. Such growth unconformities indicate a volcanic source and may represent episodes of magmatic erosion prior to expulsion from magma chambers (Prasad and Hesse, 1982). Volcanic glass fragments occur as angular shards and are frequently vesicular. Biogenic components (foraminifers, radiolarians, sponge spicules) make up a considerable proportion of sands recovered (Fig. 9).

Results of light-mineral analyses show a consistent mineralogy for the sediments of all DSDP Leg 84 sites along the landward slope of the Middle America Trench. The sediments are rich in volcanic glass and zoned plagioclase.

Sandstone compositions are determined by many factors including the nature of the sedimentary provenance, weathering in the source area, the type of processes operating in the depositional basin, and the dispersal paths linking provenance to basin (Watson, 1981). The prime control on provenance-basin relationships is the tectonic setting that ultimately governs the sandstone composition (Dickinson, 1982). Dickinson and Suczek (1979) distinguish three main provenance types: continental block, recycled orogen, and magmatic arc (Fig. 8). As expected, sands recovered from the Leg 84 sites all fall 
Table 1. Modal percentages of light minerals in Leg 84 sand samples (percentages based on 500-point counts per section).

\begin{tabular}{|c|c|c|c|c|c|c|c|c|c|}
\hline \multirow[b]{2}{*}{$\begin{array}{c}\text { Sample } \\
\text { (interval in } \mathrm{cm} \text { ) }\end{array}$} & \multirow{2}{*}{$\frac{\mathrm{L}}{\begin{array}{c}\text { Volcanic } \\
\text { glass }\end{array}}$} & \multicolumn{2}{|c|}{ F } & \multirow{2}{*}{$\frac{\mathrm{Q}}{\text { Quartz }}$} & \multirow[b]{2}{*}{ Mica } & \multirow[b]{2}{*}{ Glauconite } & \multirow[b]{2}{*}{$\begin{array}{c}\text { Heavy } \\
\text { minerals }\end{array}$} & \multirow[b]{2}{*}{$\begin{array}{c}\text { Biogenic } \\
\text { debris }\end{array}$} & \multirow[b]{2}{*}{ Age } \\
\hline & & Plagioclase & $\begin{array}{c}\text { K- } \\
\text { Feldspar }\end{array}$ & & & & & & \\
\hline $568-10-1,95-96$ & 57 & 6 & 0 & 1 & 0 & 0 & 2 & 32 & Pleistocene \\
\hline $568-12-5,108-110$ & 33 & 9 & 1 & 0 & 0 & 0 & 1 & 56 & Pleistocene \\
\hline $568-14-6,111-113$ & 12 & 59 & 2 & 5 & 0 & 1 & 1 & 20 & Pleistocene \\
\hline $568-15-6,35-36$ & 58 & 9 & 0 & 1 & 0 & 0 & 2 & 30 & Pleistocene \\
\hline $568-17-1,18-19$ & 54 & 12 & 0 & 2 & 1 & 0 & 1 & 30 & Pleistocene \\
\hline $568-22-3,102-103$ & 59 & 31 & 1 & 3 & 2 & 0 & 1 & 6 & late Miocene \\
\hline $568-24-6,5-7$ & 14 & 52 & 2 & 2 & 5 & 0 & 0 & 25 & late Miocene \\
\hline $568-25-5,82-84$ & 28 & 19 & 0 & 2 & 1 & 0 & 1 & 49 & middle Miocene \\
\hline $568-27-1,21-22$ & 73 & 22 & I & 3 & 1 & 0 & 0 & 0 & middle Miocene \\
\hline $568-29-1,98-100$ & 71 & 17 & 0 & 1 & 3 & 0 & 1 & 7 & middle Miocene \\
\hline $568-29-4,10-12$ & 70 & 21 & 0 & 3 & 3 & 1 & 1 & 1 & middle Miocene \\
\hline $568-30-4,21-23$ & 25 & 51 & 1 & 3 & 5 & 0 & 1 & 14 & middle Miocene \\
\hline $568-32-2,148-150$ & 21 & 61 & 2 & 7 & 0 & 0 & 1 & 8 & middle Miocene \\
\hline $568-42-4,45-48$ & 11 & 66 & 1 & 5 & 0 & 0 & 0 & 17 & early Miocene \\
\hline $568-43-4,70-72$ & 41 & 22 & 0 & 1 & 1 & 0 & 7 & 28 & early Miocene \\
\hline $568-44-2,25-28$ & 41 & 28 & 0 & 0 & 0 & 0 & 1 & 30 & early Miocene \\
\hline $568-30-2,21-23$ & 36 & 30 & 0 & 1 & 3 & 0 & 1 & 29 & middle Miocene \\
\hline $568-2-1,10-12$ & 76 & 5 & 0 & 3 & 1 & 0 & 1 & 14 & Pleistocene \\
\hline $565-11-1,125-127$ & 14 & 21 & 1 & 3 & 0 & 0 & 1 & 60 & e. Pleistocene \\
\hline $565-11-1,90-92$ & 54 & 33 & 1 & 2 & 0 & 0 & 2 & 8 & e. Pleistocene \\
\hline $565-23-2,60-62$ & 18 & 48 & 0 & 0 & 0 & 0 & 1 & 33 & late Pliocene \\
\hline $565-33, \mathrm{CC}$ & 74 & 12 & 1 & 1 & 0 & 0 & 3 & 0 & late Miocene \\
\hline $566-2-1,73-75$ & 21 & 67 & 2 & 3 & 0 & 1 & 2 & 4 & late Pleistocene \\
\hline $566-2-1,140-143$ & 39 & 39 & 0 & 3 & 1 & 1 & 12 & 5 & late Pleistocene \\
\hline $566-2-4,43-45$ & 68 & 30 & 1 & 0 & 1 & 0 & 0 & 0 & late Pleistocene \\
\hline $567-2-4,136-138$ & 22 & 70 & 2 & 3 & 0 & 0 & 2 & 1 & early Pliocene \\
\hline $567-6-5,42-44$ & 30 & 12 & 0 & 1 & 1 & 3 & 31 & 22 & early Miocene \\
\hline $567-10-2,110-112$ & 21 & 11 & 0 & 1 & 0 & 0 & 0 & 67 & early Miocene \\
\hline $567-11-3,31-33$ & 25 & 65 & 2 & 1 & 0 & 1 & 1 & 5 & early Miocene \\
\hline $567-13-2,14-16$ & 34 & 31 & 0 & 2 & 1 & 0 & 2 & 30 & early Miocene \\
\hline $568-3-6,97-99$ & 33 & 28 & 1 & 0 & 3 & 0 & 1 & 34 & late Pleistocene \\
\hline $568-4, \mathrm{CC}(5-6)$ & 46 & 5 & 0 & 1 & 1 & 0 & 2 & 45 & Pleistocene \\
\hline $568-5-7,22-24$ & 76 & 2 & 0 & 1 & 1 & 0 & 0 & 20 & Pleistocene \\
\hline $568-7-4,92-94$ & 18 & 63 & 0 & 2 & 1 & 0 & 1 & 15 & Pleistocene \\
\hline $568-8-4,39-44$ & 54 & 19 & 0 & 5 & 1 & 0 & 1 & 20 & Pleistocene \\
\hline $568-9, \mathrm{CC}$ & 57 & 10 & 0 & 1 & 0 & 1 & 1 & 30 & Pleistocene \\
\hline $569-3-4,29-31$ & 54 & 12 & 0 & 2 & 1 & 0 & 1 & 30 & Pleistocene \\
\hline $569-5-4,32-34$ & 37 & 11 & 0 & 2 & 0 & 0 & 0 & 50 & Pleistocene \\
\hline $569-6-3,52-54$ & 35 & 9 & 0 & 1 & 1 & 0 & 1 & 53 & Pliocene \\
\hline $569-7-1,82-83$ & 66 & 29 & 1 & 1 & 1 & 1 & 2 & 0 & late Pliocene \\
\hline $569-8-3,81-83$ & 83 & 12 & 0 & 2 & 2 & 0 & 1 & 0 & late Pliocene \\
\hline $569-9-2,3-4$ & 92 & 3 & 0 & 1 & 4 & 0 & 0 & 0 & middle Miocene \\
\hline $569-9-2,43-45$ & 41 & 13 & 0 & 6 & i & 0 & 2 & 37 & middle Miocene \\
\hline $569-10-1,21-23$ & 50 & 5 & 0 & 2 & 40 & 0 & 1 & 2 & middle Miocene \\
\hline $569-11-2,128-130$ & 74 & 9 & 0 & 2 & 1 & 0 & 1 & 13 & late Miocene \\
\hline $569-12-6,28-30$ & 64 & 18 & 1 & 2 & 11 & 0 & 1 & 3 & late Miocene \\
\hline $569-20-2,2-4$ & 46 & 18 & 0 & 1 & 2 & 0 & 1 & 32 & late Miocene \\
\hline $569-16, \mathrm{CC}$ & 71 & 9 & 0 & 2 & 1 & 0 & 0 & 17 & late Miocene \\
\hline $569-21-2,30-32$ & 6 & 68 & 1 & 6 & 3 & 0 & 15 & 1 & late Miocene \\
\hline $569-27-4,22-24$ & 89 & 7 & 0 & 3 & 1 & 0 & 0 & 0 & late Oligocene \\
\hline $570-4-2,121-123$ & 44 & 28 & 2 & 7 & 3 & 0 & 1 & 15 & Pleistocene \\
\hline $570-6-6,79-80$ & 78 & 19 & 0 & 0 & 1 & 0 & 2 & 0 & Pleistocene \\
\hline $570-14-2,108-110$ & 65 & 24 & 0 & 7 & 2 & 0 & 2 & 0 & Pleistocene \\
\hline $570-22-3,74-76$ & 40 & 10 & 0 & 3 & 2 & 0 & 1 & 44 & Pleistocene \\
\hline $570-24-1,60-62$ & 25 & 15 & 0 & 1 & 1 & 0 & 1 & 57 & Pleistocene \\
\hline $570-25-1,14-16$ & 35 & 20 & 0 & 1 & 1 & 1 & 1 & 42 & early Pliocene \\
\hline $570-27-1,2-3$ & 49 & 17 & 1 & 1 & 2 & 0 & 1 & 29 & early Pliocene \\
\hline $570-30-4,50-52$ & 45 & 19 & 1 & 3 & 1 & 0 & 1 & 30 & late Miocene \\
\hline $570-35-2,78-80$ & 72 & 15 & 0 & 5 & 8 & 0 & 0 & 0 & early Miocene \\
\hline $570-34-1,6-8$ & 34 & 13 & 0 & 1 & 2 & 0 & 1 & 49 & early Miocene \\
\hline
\end{tabular}

within the magmatic-arc field, indicating a probable source area in the Volcanic Highlands province of Guatemala.

The composition of the sands can be grouped into three main categories, which are indicative of the sediment dispersal paths (Fig. 10): (1) Graded sands composed entirely of plagioclase feldspar and weathered volcanic glass were probably transported directly from the Guatemalan shore along conduits such as the San José
Canyon by turbidity currents. (2) Graded sands composed of plagioclase feldspar, weathered volcanic glass, and biogenic components are probably hybrid sand resulting from redeposition of shelf sediments. (3) Sands rich in angular volcanic ash fragments were probably derived directly by air falls of ash after eruption.

Consistent sand composition in all samples from Miocene to Pleistocene suggests that a similar source area has existed in the vicinity of the Middle America Trench 


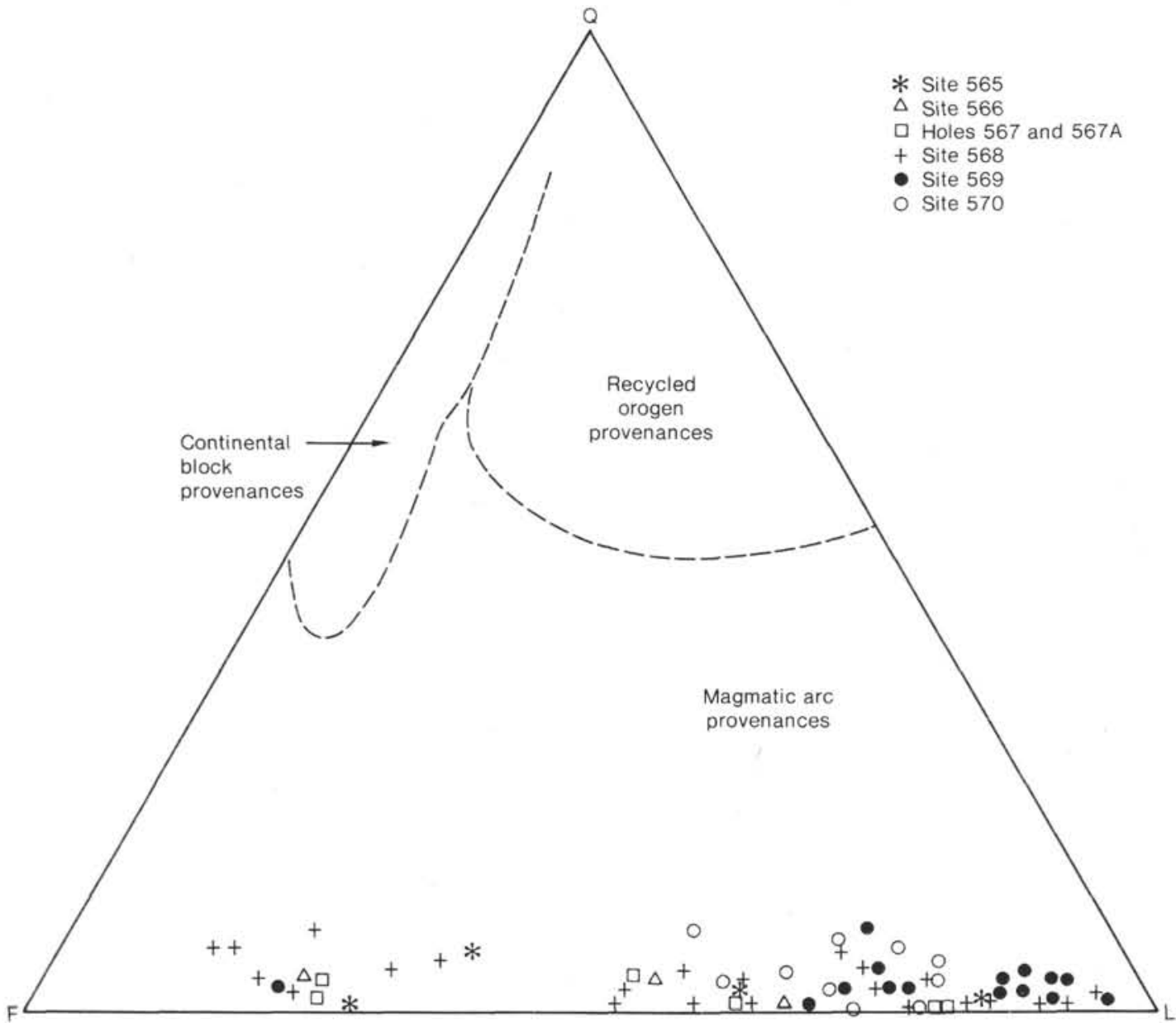

Figure 8. Ternary diagram showing quartz-feldspar-lithic fragments (QFL) in Leg 84 DSDP sand samples with provenance fields after Dickinson (1982) and Dickinson and Suczek (1979). Note that Leg 84 sand samples plot near the undissected arc area of the magmatic-arc provenance field. (Refer to Table 1 for raw data.)

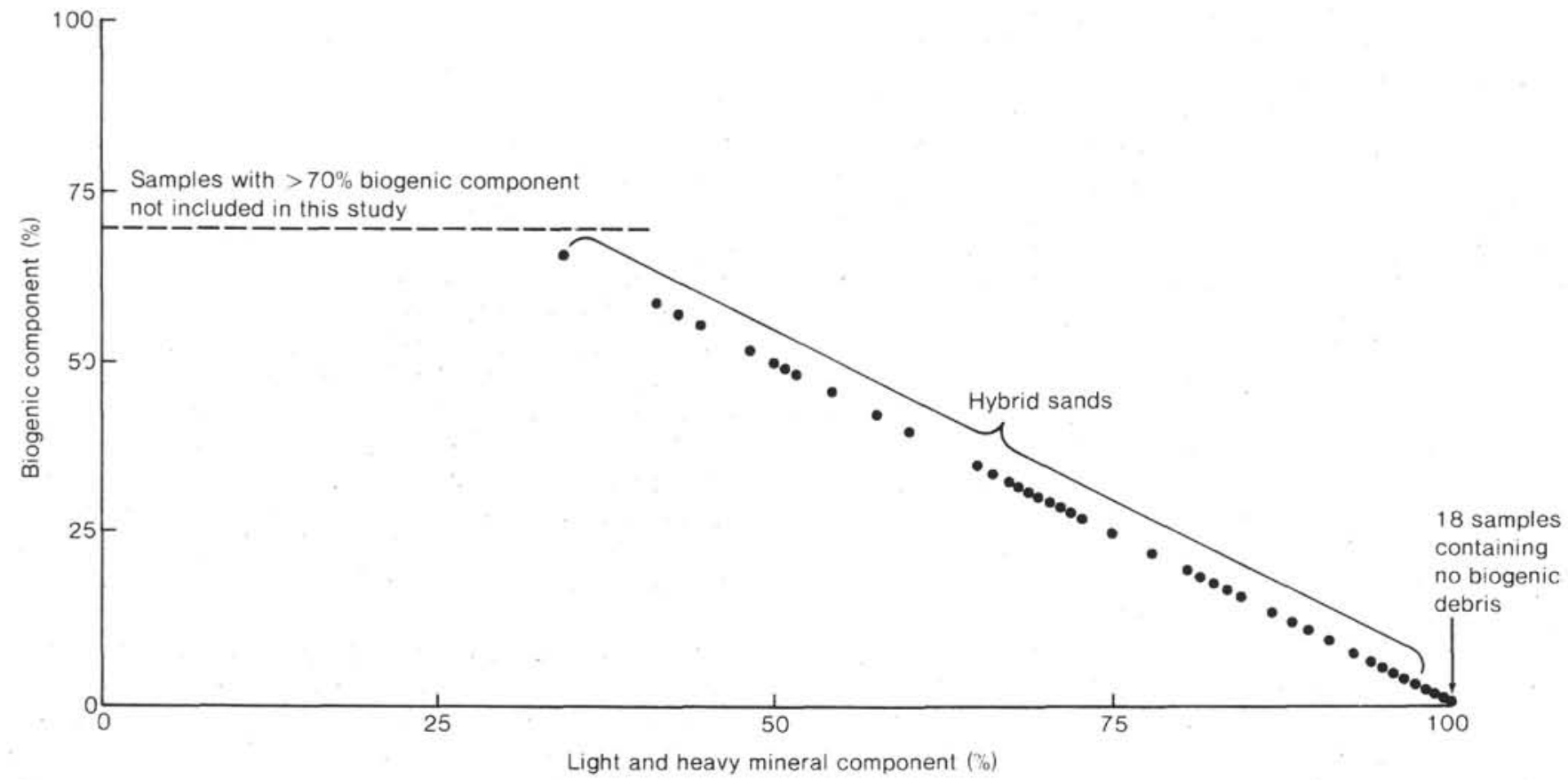

Figure 9. Percentage of biogenic debris plotted against light and heavy mineral detritus for sands recovered during Leg 84 . 


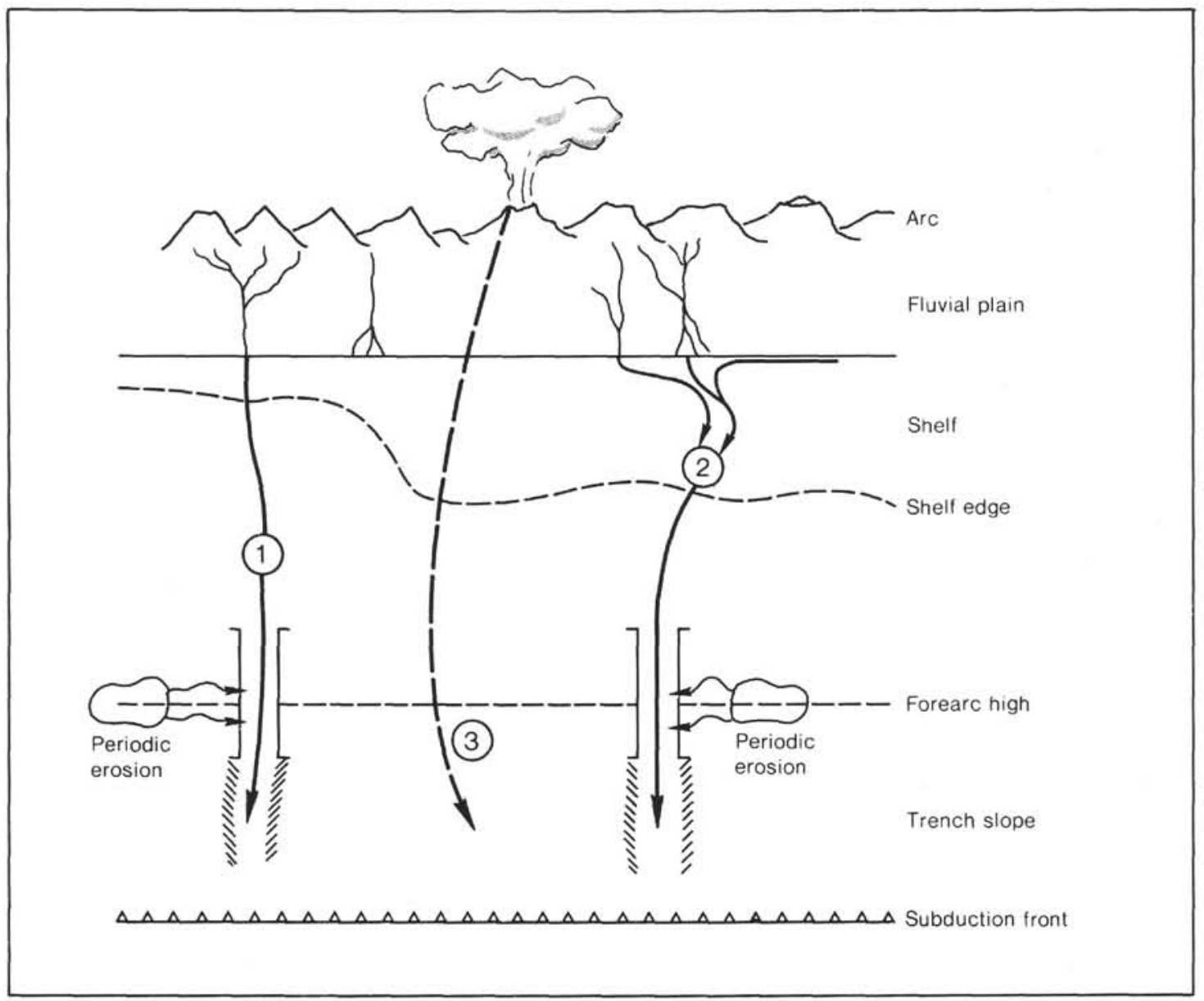

Figure 10. Schematic diagram showing major sediment dispersal paths from the Guatemalan arc. (1) Direct transport from the shelf by turbidity currents. (2) Redeposition (by slump, creep, mass wasting) of previously deposited shelf sediments from shelf and slope after mixing with local shelf faunas. (3) Direct sedimentation by air fall after eruptions on the mainland.

since the early Miocene or late Oligocene. The sandsized material is mostly volcanic ash and lithic fragments. Therefore, the light-mineral composition of sands deposited on the lower and middle slopes of the Middle America Trench demonstrates that the present-day tectonic setting of the Trench was already in existence by the beginning of the Miocene, and the presence of ash layers in Oligocene and Eocene sediments indicates that volcanism and related subduction occurred even earlier.

\section{SUMMARY AND CONCLUSIONS}

The sediment sequence covering the ophiolites that form the framework of the Guatemalan continental margin are easily divided into two distinctive lithologic sequences that also correspond roughly to Neogene and Paleogene ages. The Neogene slope deposit sequence is representative of the present sedimentological, morphological, and tectonic setting, whereas the Paleogene is more varied and thin. The sparse Eocene deposits drilled on Legs 67 and 84 may, in part, be an artifact of site location on basement highs. Erosion of Eocene and Cretaceous outcrops during the Neogene is suggested by ubiquitous occurrence of these lithologies as reworked clasts and transported microfossils.
The Neogene sediment was largely derived from the Volcanic Highlands off Guatemala. This is clearly the case for sand from studies of both Legs 67 and 84 cores (Enkebol, 1982; Prasad and Hesse, 1982; and this chapter). Silt and clay probably have a similar source in addition to authigenic clay from weathering of the igneous basement and deeper sediment. Clay and silt are more widely dispersed by currents, as shown by the $170-\mathrm{m}$ thick upper middle Miocene terrigenous mud cored $20 \mathrm{~km}$ seaward of the Trench axis at Site 495 (Aubouin, von Huene, et al., 1982). Backtracking the Cocos Plate suggests deposition some $500 \mathrm{~km}$ seaward of the Trench axis, however, and such distant transport requires special conditions. Perhaps such conditions prevailed during intensified ocean circulation associated with global cooling; associated currents may have been the cause of erosion for much of the middle and late Miocene sequence from the Guatemalan slope (Stone and Keller, this volume).

The Neogene slope deposits typically comprise massive mud. The highly monotonous mud sequence provides little impedance contrast to give acoustic images. From multichannel seismic data (von Huene et al., 1982) through high-resolution seismic data (T. Shipley and G. 
F. Moore, personal communication, 1983 ) to $3.5 \mathrm{kHz}$ deep-towed transducer surveys (Moore et al., 1982), the slope deposits are imaged with great difficulty. Reflections are generally of low amplitude and high frequency, and do image fairly well in local ponds, in the Trench axis, and where sediment had been deposited rapidly in lobes. The contrast in acoustic images between flat areas and slopes suggests that little structure survives the continual downslope creep and mass wasting that appear to prevail on slopes of the Middle America Trench.

The homogeneous mixture of grain sizes and general lack of sedimentary structures throughout the Neogene slope sediments indicate that continuous mixing during downslope creep is important in sediment transport and has been throughout the Neogene. This is supported by the ubiquitous admixture of fauna from upslope in benthic foraminiferal assemblages. Such flow could effect a consolidation of sediments at unusually shallow depths in the sediment column as clay-dominated sediment constituents are smeared together, resulting in the overconsolidation of surface and shallow sediments observed at several sites (Taylor and Bryant, this volume). Buildup of sediment could continue to a point of slope instability and failure with local slumping.

The general lack of reflections in seismic lines along the slope indicates that creep is a widespread process, but local acoustic definition of prograding lobes of sediment containing homogeneous material and the remarkable variation in sediment thicknesses among neighboring sites illustrates the importance of shifting depocenters and erosion in the upper and middle slope. The Pleistocene section is over $210 \mathrm{~m}$ thick at Site 570 and only $50 \mathrm{~m}$ thick at nearby Site 569 , whereas the Miocene is only $1 \mathrm{~m}$ thick at Site 570 compared to over $190 \mathrm{~m}$ at Site 569. The presence of coarse sand and even conglomerate well removed from the Trench axis and between present canyons and gullies in sediments of Eocene, Miocene, and younger sections shows (1) that all sand need not be transported into the Trench and (2) that an area through which sand may be transported can become a site of accumulation of sand and other material. The seismic profiles of von Huene et al. and Volpe et al. (both this volume) corroborate this depositional pattern, showing disrupted sedimentary layers and possible filled or abandoned channels. Hiatuses inferred in part from sudden changes in sediment accumulation rates also show a depositional pattern that is far from uniform over time (Fig. 3B). We envision sediment creep concentrated along prograding lobes of sediment; local slope instabilities or changes in sediment supply produces shifts in these depocenters as channels are cut off from supply or so choked with sediment as not to provide an effective conduit. The ultimate sediment sink is the Trench axis.

Closely related to the contrast in sedimentary section between neighboring sites is the localized occurrence of hydrate. Site 568 was located close to Site 496 in order to study hydrates, which were in great evidence at Site 496. But hydrates were rather poorly represented at Site 568 and visibly observed only in one interval filling the fractures of a tuffaceous mudstone. Where it was found in large amounts at Site 570, gas hydrate occurred in the interstices of coarse sediment of high porosity and permeability. Sediments of the nearby gas-ridden Site 496 are generally sandier, with several sandy to pebbly layers (Aubouin, von Huene, et al., 1982). The local variation in sediment texture may directly affect the occurrence or lack of gas hydrate. Minor textural variation and local sandy layers are features too small to resolve acoustically; it follows that many gas hydrate occurrences associated with these features will only be observable through direct sampling.

In contrast to the Middle America Trench off Mexico where drilling in the Trench axis was terminated due to caving sand (Watkins, Moore et al., 1982), sediment ponded on the Guatemalan slope contains more sand than the present turbidite fill of the Trench. The difference may depend ultimately on the volume of sediment supplied to the Trench in these two regions. The principal canyon supplying sediment to the Trench off southern Mexico (Ometepec Canyon) has a larger source area and does not cross a broad forearc basin before reaching the slope as does San José Canyon off Guatemala. The Trench axis off Guatemala received relatively fewer and principally distal turbidites. With insufficient sediment to cover the relief of the ocean basin floor that enters the Trench axis, there are only local ponds of turbidite accumulation between basement highs and no throughgoing longitudinal turbidity current channels paralleling the Trench axis (Aubouin, von Huene, et al., 1982). Sediment in the Trench off Guatemala is better sorted than that in the Trench off Mexico, and sand is poorly represented. Basins on the slope off Guatemala, however, are more proximal to the sediment source and could provide areas of lesser gradient where sand can be trapped upslope of the Trench.

Paleogene (mainly Eocene) sediment was recovered from two Leg 84 sites and one Leg 67 site; it is absent at two Leg 84 sites that penetrated basement but present in the Esso Petrel Well at the edge of the shelf (Coulbourn et al., 1982; Seely, 1979). All Eocene microfossil assemblages are from abyssal depths except at the Petrel Well and Site 494 where they are both bathyal. The varied lithologies including radiolarian mudstone, limestone, and sandstone indicate tectonically mixed lithologies and mixed sedimentary processes, especially at Site 570 near the shelf edge. Sites 494 and 569 contain more uniform Eocene radiolarian mudstone indicating deep water sedimentation. Cretaceous sediment recovered from the foot of the slope at Sites 567 and 494 is blue gray micritic limestone, indicating a pelagic or oceanic paleoenvironment removed from terrigenous sediment sources.

The Cretaceous and Paleocene section beneath the forearc basin has a terrigenous provenance, and it accumulated in a body of sediment estimated by von Huene et al. (this volume) to have been $100 \mathrm{~km}$ wide. Eocene and Oligocene sediments in the forearc basin are 1.5 to $5 \mathrm{~km}$ thick and include terrigenous and biogenic material; only a few tens of meters of Eocene and Oligocene sediments were recovered on the slope. Von Huene et al. 
(this volume) suggest the Eocene and minor Oligocene slope sediments may represent distal, deeper equivalents of the forearc basin sediments and could be consistent with the present continental margin configuration. Cretaceous sediment beneath the forearc basin and beneath the slope was deposited in settings more distinct from each other than where they are presently found.

Tectonic juxtaposition of the oceanic Cretaceous section against the shelf section probably occurred between the end of the Cretaceous and late Eocene either by convergence (thrust faulting; possibly subduction) resulting in deformation, telescoping and accretion of the section to its present slope location, or by transverse faulting (von Huene et al., this volume). Subduction along the present zone began after this with consequent uplift of the slope and the edge of the forearc basin.

Such a scenario explains the limited but varied suite of Eocene upper slope sediments and suggests a reason for the paucity of Oligocene sediments on the slope: regional uplift of this margin would result in nondeposition or even erosion, particularly if uplift along the shelf edge created a continuous forearc structural high to dam sediment in the forearc basin.

Continued subduction and consequent on-land volcanism resulted in a tremendous volume of volcanic terrigenous sediment that blanketed the continental margin despite continued uplift during the Neogene. Local hiatuses developed as described earlier, and periodic regional erosion or nondeposition occurred during interplay of sea level changes and continued uplift (Seely, 1979).

Leg 84 shipboard scientists left the Challenger confident that the unrepeated, ordered stratigraphic sequence of sediments drilled on the Guatemalan slope dispelled the notion of post-Eocene accretion of sediment or crustal block to the Guatemalan continental margin. The accumulation of sediment along the Trench axis was recognized as sediment ponding in a depression; the thickness of Trench axis sediment is far less than would be expected if Cocos Plate subduction had offscraped sediment along the margin since the Paleogene. Nevertheless, a few details remain to complicate the simple scenario of subduction without accretion.

Very minor amounts of Miocene chalk (one 6-cm clast from 567-18, CC at the foot of the slope and a few smaller pieces in a University of Texas Marine Sciences Institute gravity core also taken near the foot of the slope-Baltuck et al., this volume) are similar in lithology and depositional paleoenvironment to the Miocene chalk drilled on the Cocos Plate during Leg 67. The location of these pieces in the Neogene slope apron just above the Trench may ultimately result in their downslope transport and subduction, but their presence on the landward side of the Trench indicates that a complete dismissal of sediment accretion during subduction along the present Guatemalan continental margin would be an oversimplification.

\section{ACKNOWLEDGMENTS}

The authors wish to thank William T. Coulbourn and Neil Lundberg for their critiques of an earlier draft of this chapter.

\section{REFERENCES}

Aubouin, J., von Huene, R., et al., 1982. Init. Repts. DSDP, 67: Washington (U.S. Govt. Printing Office).

Carson, B., 1977. Tectonically induced deformation of deep sea sediments off Washington and northern Oregon: mechanical consolidation. Mar. Geol., 24:289-307.

Carson, B., von Huene, R., and Arthur, M., 1982. Small-scale deformation structures and physical properties related to convergence in Japan Trench slope sediments. Tectonics, 1(3):277-302.

Coulbourn, W. T., Hesse, R., Azéma, J., and Shiki, T., 1982. A summary of the sedimentology of the Deep Sea Drilling Project Leg 67 sites: the Middle America Trench and slope off Guatemala - an active margin transect. In Aubouin, J., von Huene, R., et al., Init. Repts. DSDP, 67: Washington (U.S. Govt. Printing Office), 759-774.

Cowan, D. S., 1982. Origin of "vein structure" in slope sediments on the inner slope of the Middle America Trench off Guatemala. In Aubouin, J., von Huene, R., et al., Init. Repts. DSDP, 67: Washington (U.S. Govt. Printing Office), 645-650.

Dengo, G., 1972. Review of Caribbean serpentinites and their tectonic implications. Geol. Soc. Am. Mem., 130:303-312.

Dickinson, W. R., 1970. Interpretating detrital modes of graywacke and arkose. J. Sed. Petrol., 40:695-707.

1971. Clastic sedimentary sequences deposited in shelf, slope and trough settings between magmatic arcs and associated trenches. Pacific Geol., 3:15-30.

1982. Compositions of sandstones in circum-Pacific subduction complexes and forearc basins. Bull. Am. Assoc. Petrol. Geol., 66:121-137.

Dickinson, W. R., and Suczek, C. A., 1979. Plate tectonics and sandstone compositions. Bull. Am. Assoc. Petrol. Geol., 63:2164-2182.

Enkeboll, R. H., 1982. Petrology and provenance of sands and gravels from the Middle America Trench and Trench slope, southwestern Mexico and Guatemala. In Watkins, J. S., Moore, J. C., et al., Init. Repts. DSDP, 66: Washington (U.S. Govt. Printing Office), 521-530.

Graham, S. A., Ingersoll, R. V., and Dickinson, W. R., 1976. Common provenance for lithic grains in carboniferous sandstones from the Ouachita Mountains and Black Warrior Basin. J. Sediment. Petrol., 46:620-632.

Ibrahim, A. K., Latham, G. V., and Ladd, J., 1979. Seismic refraction and reflection measurements in the Middle America Trench offshore Guatemala. J. Geophys. Res., 84:5643-5649.

Ingersoll, R. V., 1978. Petrofacies and petrologic evolution of the Late Cretaceous forearc basin, northern and central California. J. Geol., $86: 335-352$.

Karig, D. E., and Sharman, G. F., 1975. Subduction and accretion in trenches. Bull. Geol. Soc. Am., 86:377-389.

Ladd, J. W., Ibrahim, A. K., McMillen, K. J., Latham, G. V., and von Huene, R. E., 1982. Interpretation of seismic-reflection data of the Middle America Trench offshore Guatemala. In Aubouin, J., von Huene, R. et al., Init. Repts. DSDP, 67: Washington (U.S. Govt. Printing Office), 675-690.

Minster, J. B., and Jordan, T. H., 1978. Present-day plate motions. J. Geophys. Res., 83:5331-5354.

Moore, G. F., Lonsdale, P., and von Huene, R., 1982. Near-bottom observations of the Middle America Trench off Guatemala. In Aubouin, J., von Huene, R., et al., Init. Repts. DSDP, 67: Washington (U.S. Govt. Printing Office), 707-718.

Prasad, S., and Hesse, R., 1982. Provenance of detrital sediments from the Middle America Trench transect off Guatemala, Deep Sea Drilling Project 67. In Aubouin, J., von Huene, R., et al., Init. Repts. DSDP, 67: Washington (U.S. Govt. Printing Office), 507-514.

Rosenfeld, J. H., 1981. Geology of the western Sierra de Santa Cruz, Guatemala, Central America: an ophiolite sequence [Ph.D. thesis]. State University of New York at Binghampton.

Scholl, D. W., Marcow, M. S., and Cooper, A. K., 1977. Sediment subduction and offscraping at Pacific Margins. In Talwani, M., and Pitman, W. C., III (Eds.), Island Arcs, Deep Sea Trenches and Back-Arc Basins: Washington (Am. Geophys. Union), Maurice Ewing Ser. No. 1, pp. 199-210.

Seely, D. R., 1979. The evolution of structural highs bordering major forearc basins. In Watkins, J. S., Montadert, L., and Dickerson, P. 
W. (Eds.), Geological and Geophysical Investigations of Continental Margins. Am. Assoc. Petrol. Geol. Mem., 29:245-260.

Seely, D. R., Vail, P. R., and Walton, G. G., 1974. Trench slope model. In Burke, C. A., and Drake, C. L. (Eds.), The Geology of Continental Margins: New York (Springer-Verlag), pp. 249-260.

Shipley, T. H., Ladd, J. W., Buffler, R. T., and Watkins, J. S., 1982. Tectonic processes along the Middle America trench inner slope. In Legget, J. K. (Ed.), Trench-forearc Geology: Sedimentation and Tectonics on Modern and Ancient Active Plate Margins. Geol. Soc. London Spec. Publ., 10:95-106. von Huene, R., Ladd, J., and Norton, I., 1982. Geophysical observations of slope deposits, Middle America Trench off Guatemala. In Aubouin, J., von Huene, R., et al., Init. Repts. DSDP, 67: Washington (U.S. Govt. Printing Office), 719-732.

Watkins, J. S., Moore, J. C., et al., 1982. Init. Repts. DSDP, 66: Washington (U.S. Govt. Printing Office).

Watson, M. P., 1981. Submarine fan deposits of the upper Ordovician-lower Silurian Milliners Arm Formation, New World Island, Newfoundland [Ph.D. thesis]. University of Oxford, Oxford, England. 